\title{
The orphan nuclear receptors at their 25-year reunion
}

\author{
Shannon E Mullican*, Joanna R DiSpirito* and Mitchell A Lazar \\ Division of Endocrinology, Diabetes, and Metabolism, Department of Medicine, and The Institute for Diabetes, \\ Obesity, and Metabolism, Perelman School of Medicine at the University of Pennsylvania, Philadelphia, \\ Pennsylvania 19104, USA \\ *(S E Mullican and J R DiSpirito contributed equally to this work)
}

Correspondence should be addressed to M A Lazar Email

lazar@mail.med.upenn.edu

\begin{abstract}
The nuclear receptor superfamily includes many receptors, identified based on their similarity to steroid hormone receptors but without a known ligand. The study of how these receptors are diversely regulated to interact with genomic regions to control a plethora of biological processes has provided critical insight into development, physiology, and the molecular pathology of disease. Here we provide a compendium of these so-called orphan receptors and focus on what has been learned about their modes of action, physiological functions, and therapeutic promise.
\end{abstract}

\section{Key Words}

- orphan nuclear receptor

\section{Introduction}

In the late 1980s the observation that the steroid hormone receptors shared highly conserved domains encouraged researchers to search for additional members of the nuclear receptor (NR) family (Mangelsdorf et al. 1995, Giguère 1999, Willson \& Moore 2002, Benoit et al. 2006). Unlike that of the classic NRs that had previously been identified with prior knowledge of a naturally occurring ligand, these new members were initially without ligand, and therefore referred to as orphans. Over the span of a decade, using probes designed from conserved NR domains to screen cDNA libraries and degenerate primers for target amplification, as well as automated searches of EST databases, 36 vertebrate orphan NRs were identified (Fig. 1; Willson \& Moore 2002).

Orphan NRs consist of the four major domains that characterize classic nuclear hormone receptors (Aranda \& Pascual 2001, Huang et al. 2010, Helsen et al. 2012). The amino terminus contains the A/B domain consisting of activation function 1 (AF1) and among orphans, this region is quite variable in size. The DNA-binding domain (DBD) consists of two zinc finger motifs and confers response element specificity; it is typically highly conserved within orphan receptor subgroups. Linking the DBD to the carboxy-terminal ligand-binding domain (LBD) is the hinge region, whose length varies between subfamilies. The pocket formed by the LBD can also vary greatly in size and by the absence or presence of the AF2 region that mediates coactivator interaction.

Classic NRs are transcription factors regulated by the high affinity binding of naturally occurring small molecules, which dictate receptor subcellular localization and conformation. The latter determines coactivatorrepressor interactions and thereby transactivation potential (Mangelsdorf et al. 1995, Aranda \& Pascual 2001). In contrast, while the regulation of gene transcription by orphan NRs also depends on interactions with coactivator and corepressor complexes, the role of ligand varies (Benoit et al. 2004, Markov \& Laudet 2011). Nevertheless, once an endogenous ligand has been identified, the corresponding orphan is then considered 'adopted' (Benoit et al. 2006).

Due to their potential ligand regulation, orphan NRs have the prospect of serving as therapeutic targets of small molecules (Mukherjee \& Mani 2010). Thus, there has been an intense focus on the physiological roles and molecular 


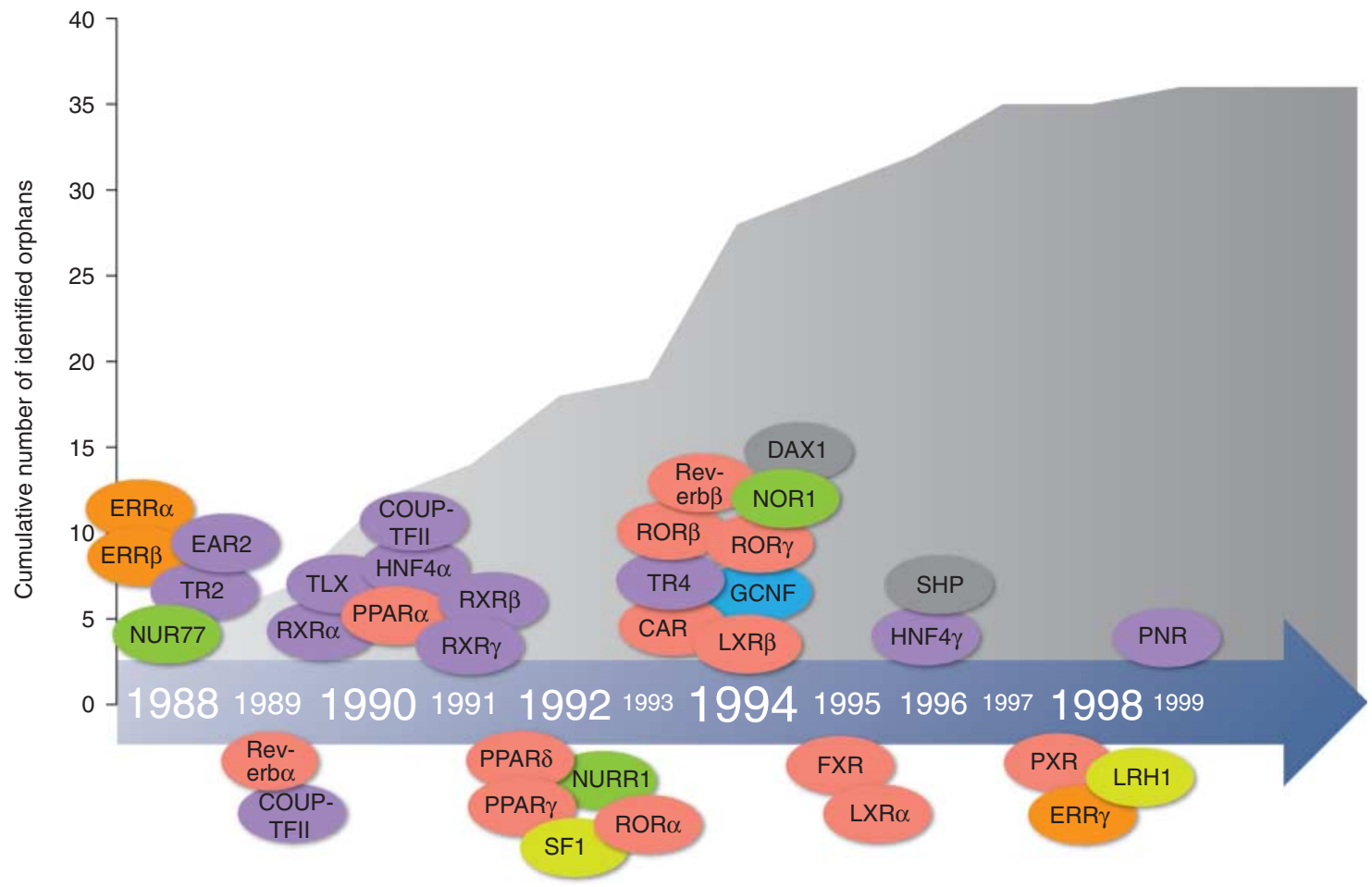

\section{Figure 1}

Orphan NR Timeline. From the late 1980s till the end of the 1990s, there was rapid growth of the NR superfamily with the addition of 36 orphan members. Once the cloning and discovery of novel members plateaued, the

mechanisms of orphan NRs over the last 25 years (Benoit et al. 2006). All vertebrate orphan NRs have been globally deleted in mice and some have been overexpressed and/or selectively targeted spatially and/or temporally. To illustrate the enormous impact of this technology on our understanding of orphan NR biology, all relevant mouse models are summarized in Table 1.

There are many orphan NRs in mammals as well as in lower organisms. Orphan NRs in Drosophila melanogaster and Caenorhabditis elegans have been reviewed elsewhere (Taubert et al. 2011, Fahrbach et al. 2012). Here, we review current knowledge about each of the 36 orphan NRs that has a human ortholog. The entire NR superfamily has been categorized into six structurally distinct groups based on phylogenetic analysis, producing a unified nomenclature system that identifies each NR with less ambiguity (Laudet 1997, Nuclear Receptors Nomenclature Committee 1999, Germain et al. 2006). In this review, each orphan is introduced as part of its official NR group, then addressed by its most commonly used name. The discussion of each is necessarily brief, highlighting its discovery, regulation, and physiological functions, particularly those with therapeutic implications. For focus of the field shifted to intense functional characterization. Here each orphan is listed by its common name and color-coded based on its designated NR subfamily.

more detailed information on individual NRs, readers are directed to the NURSA website (www.nursa.org) and to more comprehensive reviews.

\section{The odd ones: orphans of the NROB group}

\section{NrOb1/Dax1 and Nr0b2/Shp}

DAX1 and SHP are atypical NRs harboring a classifiable NR LBD in their carboxyl-terminus, but lack a classic NR DBD and instead have a region resembling the NR interaction motifs characteristic of coactivators (Zanaria et al. 1994, Seol et al. 1996, Lalli \& Sassone-Corsi 2003, Båvner et al. 2005, Ehrlund \& Treuter 2012). The name small heterodimer partner $(S h p)$ reflects the ability of SHP and DAX1 to bind to the AF2 of other NRs, preventing coactivator recruitment while recruiting corepressor complexes and acting as transcriptional repressors (Lalli \& Sassone-Corsi 2003, Båvner et al. 2005, Ehrlund \& Treuter 2012). While most reports indicate that DAX1 and SHP function as transcriptional repressors, they may also enhance transcription (Kim et al. 2001, Nishizawa et al. 2002, Xu et al. 2009, Kelly et al. 2010).

Published by Bioscientifica Ltd 
Table 1 Phenotypes of orphan receptor mutant mouse strains. Orphan NR mutant strains that have been published and are listed in the Mouse Genome Informatics (MGI) database. We have listed the general physiological systems and functions affected by each mutation. For more details, see the MGI resource (www.informatics.jax.org) from which this information was collated

\begin{tabular}{|c|c|}
\hline Receptor & Embryonic lethal \\
\hline DAX1 (NR0B1) & No \\
\hline SHP (NR0B2) & No \\
\hline
\end{tabular}

PPAR $\alpha(N R 1 C 1) \quad$ No

PPAR $\beta / \delta(N R 1 C 2) \quad$ Yes

PPAR $\gamma($ NR1C3) $\quad$ Yes

REV-ERB $\alpha$ (NR1D1) No

$\begin{array}{ll}\text { REV-ERB } \beta \text { (NR1D2) } & \text { No } \\ \text { REV-ERB } \alpha / \beta & \text { No } \\ \text { ROR } \alpha(N R 1 F 1) & \text { No }\end{array}$

ROR $\beta$ (NR1F2)

ROR $\gamma($ NR1F3)

LXR $\beta$ (NR1H2)

No

$\mathrm{LXR} \alpha(\mathrm{NR} 1 \mathrm{H} 3)$

\begin{tabular}{l} 
Whole body mutants \\
\hline KO: fertility (males) \\
KO: fertility; energy expenditure, \\
cholesterol metabolism, hepatic \\
inflammation (diet-induced) \\
KO: fatty acid oxidation (fasting); \\
cholesterol and TG metabolism; \\
glycemic control (HFD); cardiac \\
fibrosis; wound healing \\
KO: placentation; growth; dyslipidemia; \\
cancer; myelination; energy expendi- \\
ture; cholesterol and TG metabolism
\end{tabular}

KO: death by E10.5 (placentation) KI (hypomorphic): premature death, AT deposition, glycemic control, TG metabolism

KI (Pro12Ala): body weight; glycemic control; TG + cholesterol metabolism

KI (P465L): embryonic lethal; BAT activity (het)

KI (L466A): embryonic lethal; AT deposition, TG metabolism, glycemic control (hets)

KI (S112A): glycemic control

KO (Mox2-Cre): AT deposition, glycemic control, blood pressure; circadian rhythm

KO ( $\gamma 2$ isoform only): AT deposition (strain-dependent); glycemic control

KO ( $\gamma 2$ isoform only): AT deposition (strain-dependent); glycemic control

KO: postnatal lethality; fertility; circadian (behavior, cholesterol and TG metabolism, immune response); bile acids; cerebellar

KO: no reported abnormalities NR

ENU: postnatal lethality; cerebellar; paralysis

KO: viability; atherosclerosis; cerebellar; cholesterol and TG homeostasis; fertility; adrenal; hematopoietic

KO: postnatal lethality; growth; fertility; learning/memory; motor; ocular

KO: hematopoietic

KO: fertility; skin; CNS (amyloid deposition)

KO: cholesterol and TG homeostasis (high cholesterol diet); infection

$\mathrm{KI}$ : constitutively active LXRa confers resistance to LPS-induced lung injury
Tissue-specific mutants

NR

Liver: cholesterol and TG metabolism

Muscle (transgene): glycemic control (HFD)

Heart (transgene): TG and cholesterol metabolism

Adipose/brain/macrophage: normal

Pan-hematopoietic: atherosclerosis; glycemic control (HFD); hematopoietic

Myeloid: autoimmunity; glycemic control (HFD)

Skeletal muscle: glycemic control; fiber type; regeneration

Pancreas: insulin secretion

Heart (transgene): glycemic control

Pancreas: beta cell mass

I-Pancreas: no beta cell defects

Heart: hypertrophy, systolic function

Myeloid: autoimmunity; glycemic control; polarization; glycemic control (HFD), immunity to infection; atherosclerosis

Kidney: body weight, blood volume

Liver: TG metabolism, glycemic control

Muscle: AT deposition; glycemic control

Lung epithelium: lung structure

Mammary epithelium: no mammary defects

Ovary: ovulation (pre-ovulatory follicles)

Endothelium/BM: TG metabolism; blood pressure rhythms

Treg: adipose inflammation (HFD)

$B$ cell: antibody production

CNS: no abnormalities reported

Adipose (aP2): AT deposition; body weight; glycemic control

I-Adipose (aP2): AT maintenance NR

NR

DKO liver: circadian; dyslipidemia

NR

NR

T cell: autoimmunity

NR

Liver: cholesterol and TG homeostasis (high cholesterol diet); atherosclerosis http://jme.endocrinology-journals.org DOI: 10.1530/JME-13-0212
() 2013 Society for Endocrinology Printed in Great Britain
Published by Bioscientifica Ltd 
Table 1 Continued

\begin{tabular}{|c|c|c|c|}
\hline Receptor & Embryonic lethal & Whole body mutants & Tissue-specific mutants \\
\hline $\operatorname{LXR} \alpha \beta$ & No & \multicolumn{2}{|c|}{$\begin{array}{l}\text { DKO: CNS (lipid deposits); cholesterol and TG metabolism; immunity to infection; } \\
\text { fertility }\end{array}$} \\
\hline FXR (NR1H4) & No & KO: bile acids; dyslipidemia & $\begin{array}{l}\text { Liver: bile acids; dyslipidemia } \\
\text { Intestine: bile acids }\end{array}$ \\
\hline PXR (NR1I2) & No & $\begin{array}{l}\text { KO: xenobiotic response } \\
\text { KI: species-specific xenobiotic responses } \\
\text { (human) }\end{array}$ & NR \\
\hline CAR (NR1I3) & No & $\begin{array}{l}\text { KO: xenobiotic response; lipid homeo- } \\
\text { stasis; body weight (caloric restriction) } \\
\text { KI: species-specific xenobiotic responses } \\
\text { (human) }\end{array}$ & NR \\
\hline HNF4 $\alpha(N R 2 A 1)$ & Yes & $\begin{array}{l}\text { KO: embryogenesis, die before E10.5 } \\
\mathrm{KI} \text { : glycemic control (a1 isoform only) } \\
\mathrm{KI} \text { : dyslipidemia (a7 isoform only) }\end{array}$ & $\begin{array}{l}\text { Liver: hepatogenesis; glycogen; lipid } \\
\text { homeostasis body weight; viability } \\
\text { Beta cell: insulin secretion }\end{array}$ \\
\hline HNF4 $\gamma(N R 2 A 2)$ & No & $\begin{array}{l}\text { KO: body weight; locomotor activity and } \\
\text { energy expenditure (circadian) }\end{array}$ & NR \\
\hline $\mathrm{RXR} \alpha(\mathrm{NR} 2 \mathrm{~B} 1)$ & Yes & $\begin{array}{l}\text { KO: cardiac, ocular and placental defects, } \\
\text { die before E16.5 } \\
\text { KO AF-1 only: partial postnatal lethality; } \\
\text { cardiac; ocular; growth retardation }\end{array}$ & $\begin{array}{l}\text { Liver: lipid and cholesterol metabolism, } \\
\text { bile acids (high cholesterol diet); body } \\
\text { weight, glycemic control (HFD) } \\
\text { I-Liver: regeneration } \\
\text { I-Adipose (aP2): body weight } \\
\text { Macrophage: autoimmunity; endotoxin } \\
\text { response } \\
\text { Epicardium: cardiovascular develop- } \\
\text { mental defects } \\
\text { Retina: photoreceptors } \\
\text { Skin: hair and coat color } \\
\text { Prostate: pre-neoplastic lesions }\end{array}$ \\
\hline RXRß (NR2B2) & Partial & $\begin{array}{l}\text { KO: viability, fertility } \\
\text { KO AF2 only: cholesterol metabolism }\end{array}$ & NR \\
\hline $\mathrm{RXR} \gamma(\mathrm{NR} 2 \mathrm{~B} 3)$ & No & $\begin{array}{l}\text { KO: thyroid; cholinergic neurons; } \\
\text { CNS re-myelination }\end{array}$ & NR \\
\hline $\mathrm{RXR} \alpha / \beta / \gamma$ & Multiple combin & al KO, see MGI database for details & \\
\hline TR2 (NR2C1) & No & KO: fetal hemoglobin & NR \\
\hline TR4 (NR2C2) & Partial & $\begin{array}{l}\text { KO: viability; aging; growth; } \\
\text { fertility; cerebellar; body weight, } \\
\text { glycemic control, lipid homeostasis, } \\
\text { energy expenditure, inflammation } \\
\text { (HFD) }\end{array}$ & NR \\
\hline TR2/4 & Yes & DKO: embryogenesis, die before E12 & \\
\hline TLX (NR2E1) & No & $\begin{array}{l}\text { KO: CNS (limbic development); } \\
\text { neurogenesis (adult); growth; } \\
\text { fertility; ocular; aggression }\end{array}$ & $\begin{array}{l}\text { CNS: aggression } \\
\text { I-CNS: spatial learning }\end{array}$ \\
\hline PNR (NR2E3) & No & KO: ocular (retina, rods and cones) & NR \\
\hline COUP-TFI (NR2F1) & No & KO: viability (brain development) & \\
\hline COUP-TFII (NR2F2) & Yes & $\begin{array}{l}\text { KO: angiogenesis and cardiac } \\
\text { development } \\
\text { I-KO: lymphatic (induction of systemic } \\
\text { Cre at E8.5); fertility (induction of } \\
\text { Cre at P14) }\end{array}$ & $\begin{array}{l}\text { Uterus: placentation } \\
\text { Endothelium: venous and lymphatic } \\
\quad \text { development } \\
\text { Beta cells: insulin secretion } \\
\text { Stomach: morphogenesis }\end{array}$ \\
\hline COUP-TFI/II & No & & DKO eye: morphogenesis \\
\hline EAR-2 (NR2F6) & No & $\begin{array}{l}\text { KO: circadian rhythm; thermal } \\
\text { nocioception; autoimmunity }\end{array}$ & NR \\
\hline$E R R \alpha(N R 3 B 1)$ & No & $\begin{array}{l}\text { KO: adipose deposition; stress } \\
\text { susceptibility (cardiac, temperature, } \\
\text { infection); bone structure }\end{array}$ & NR \\
\hline ERR $\beta$ (NR3B2) & Yes & KO: death by E10.5 (placentation) & $\begin{array}{l}\text { Embryonic: hearing (inner ear } \\
\text { development) }\end{array}$ \\
\hline$E R R \gamma(N R 3 B 3)$ & No & $\begin{array}{l}\text { KO: viability; cardiac; spinal cord; } \\
\text { kidney }\end{array}$ & NR \\
\hline
\end{tabular}


Table 1 Continued

\begin{tabular}{|c|c|c|c|}
\hline Receptor & Embryonic lethal & Whole body mutants & Tissue-specific mutants \\
\hline NURR77 (NR4A1) & No & KO: body weight (HFD); atherosclerosis & NR \\
\hline NURR1 (NR4A2) & No & $\begin{array}{l}\text { KO: complete postnatal lethality } \\
\text { by } 12 \mathrm{~h} \text {; selective loss of dopaminergic } \\
\text { neurons }\end{array}$ & NR \\
\hline NOR1 (NR4A3) & Yes & $\begin{array}{l}\text { KO: death by E8.5 (gastrulation); seizures; } \\
\text { inner ear; atherosclerosis }\end{array}$ & NR \\
\hline NURR77/NOR1 DKO & No & $\begin{array}{l}\text { KO: viability; leukemia (growth, } \\
\text { hepatomegaly, anemia) }\end{array}$ & NR \\
\hline \multirow[t]{3}{*}{ SF1 (NR5A1) } & \multirow[t]{3}{*}{ No } & $\begin{array}{l}\text { KO: viability (adrenals); gonads; } \\
\text { hypothalamus }\end{array}$ & $\begin{array}{l}\text { Anterior pituitary: fertility (gonad } \\
\text { maturation) }\end{array}$ \\
\hline & & $\begin{array}{l}\mathrm{KI}: \mathrm{K} 119 \text { and } \mathrm{K} 194 \text { mutated to } \mathrm{R}, \\
\text { loss of sumoylation on those residues }\end{array}$ & $\begin{array}{l}\text { Gonads: fertility (gonad } \\
\text { maturation) }\end{array}$ \\
\hline & & $\begin{array}{l}\text { associated with abnormal adrenal } \\
\text { function and infertility }\end{array}$ & $\begin{array}{l}\text { CNS: behavior (anxiety); body weight } \\
\text { (HFD) }\end{array}$ \\
\hline \multirow[t]{3}{*}{ LRH-1 (NR5A2) } & \multirow[t]{3}{*}{ Yes } & KO: death before E7.5 & Liver: slight dyslipidemia; bile acid \\
\hline & & HET: intestinal crypts & composition \\
\hline & & & $\begin{array}{l}\text { Intestine: slight dyslipidemia } \\
\text { Gonads: fertility (ovulation) }\end{array}$ \\
\hline GCF (NR6A1) & Yes & KO: death by E10.5 (cardiac development) & $\begin{array}{l}\text { Oocyte: fertility (oocyte morphology, } \\
\text { steroidogenesis) }\end{array}$ \\
\hline
\end{tabular}

KO, knock-out; DKO, double knock-out; KI, knock-in; I, inducible Cre transgene; NR, not yet reported; AT, adipose tissue; HFD, high-fat diet; TG, triglyceride.

To date, no ligands for the NROB receptors have been well-established, although retinoid-related molecules have been reported to bind and enhance the repressive function of SHP (Miao et al. 2011, Ehrlund \& Treuter 2012). Indeed, a crystal structure study of DAX1 demonstrated a ligand-binding pocket (LBP) filled with amino acid side chains, suggesting typical ligand regulation of this orphan to be unlikely (Sablin et al. 2008). Sequence conservation between $\mathrm{NrOb}$ group members suggests this to be a shared characteristic, and thus, it appears that the $\mathrm{NrOb}$ group is regulated at the level of expression, alternative splicing, posttranslational modifications, and miRNA targeting (Hossain et al. 2004, Miao et al. 2009, Xiao et al. 2012, Seok et al. 2013).

Although DAX1 and SHP are mechanistically very similar, their tissue expression patterns are distinct, suggesting different physiological roles (Ehrlund \& Treuter 2012). NrOb1 was originally identified as a gene frequently deleted or mutated in X-linked adrenal hypoplasia congenita (AHC) and also duplicated in dosage-sensitive sex reversal (DSS), leading to its more common name, DSSAHC critical region on the X, gene 1, or Dax1 (Muscatelli et al. 1994, Zanaria et al. 1994, Lalli \& Sassone-Corsi 2003). Dax1 is highly expressed in the hypothalamic-pituitaryadrenal-gonadal axis and has essential roles in gametogenesis and sex specification mediated in part by repression of NR5A1 (SF1; Lalli \& Sassone-Corsi 2003, Iyer \& McCabe 2004). In contrast, Shp is highly expressed in the liver and small intestine, where it represses NR5A2 (LRH1) to regulate cholesterol, bile acid (BA), and glucose metabolism (Båvner et al. 2005, Chanda et al. 2008).

Both members of the $\mathrm{NrOb}$ group have also been reported to repress the transcriptional activity of other factors besides NRs (Kim et al. 2004, 2012, Suh et al. 2006, Kinsey et al. 2009, Sun et al. 2009, Yuk et al. 2011). For example, SHP functions as a corepressor of NF- $\mathrm{KB}$ during inflammatory Toll-like receptor signaling (Yuk et al. 2011). Moreover, the ability to bind and repress OCT4 activity has identified DAX1 as a critical component in maintaining embryonic stem cell pluriopotency (Wang et al. 2006, Kim et al. 2008, Sun et al. 2009). Finally, the potential role of $\mathrm{NrOb}$ receptors in carcinogenesis is highlighted by the functional interaction of DAX1 with the EWS/FLI fusion protein in Ewing's sarcoma (Kinsey et al. 2009).

\section{There for dinner: orphans of the NR1C group}

\section{Nr1c1/Ppar $\alpha$, Nr1c2/Pparß or $\delta$, and Nr1c3/Ppar $\gamma$}

Peroxisome proliferator-activated receptors (PPARs) regulate carbohydrate and lipid metabolism in major metabolic organs (liver, adipose, and muscle) as well as

Published by Bioscientifica Ltd 
in peripheral tissues with metabolic roles (intestine, hematopoietic, and hypothalamic). The 'PPAR' name followed the discovery that PPAR $\alpha$ was activated by clofibrate, a lipid-lowering drug that causes peroxisome proliferation in the rodent liver (Issemann \& Green 1990); however, the $\beta / \delta$ and $\gamma$ subtypes have not been shown to cause peroximsomal proliferation. Despite ongoing searches for dominant endogenous ligands, the PPARs are now commonly thought of as 'sensors' for a wide range of fatty acid molecules, a promiscuity that may be explained by their large LBP (Nolte et al. 1998, Uppenberg et al. 1998, Xu et al. 1999, 2001, Michalik 2006). However, high affinity and relatively specific synthetic ligands exist for each PPAR (Bensinger \& Tontonoz 2008). As noted earlier, lipid-lowering fibrates activate $\operatorname{PPAR} \alpha$, and agonists of PPAR $\gamma$ function as anti-diabetic drugs (Lehrke $\&$ Lazar 2005).

Activation of PPAR $\alpha$ and PPAR $\beta / \delta$ supports fatty acid oxidation (FAO) in the heart, liver, and muscle, while PPAR $\gamma$ promotes lipid storage in adipose tissue (Michalik 2006). Thus, loss of PPAR $\alpha$ in the liver blocks elevated FAO in response to fasting, leading to hepatic and myocardial lipid accumulation, hypoglycemia, and elevated serumfree fatty acids (Kersten et al. 1999, Leone et al. 1999). Similarly, PPAR $\beta / \delta$ activity in the muscle promotes formation of highly oxidative slow-twitch fibers, in part through its positive regulation of PGC1 $\alpha$ (Evans et al. 2004, Schuler et al. 2006). Interestingly, these two receptors have opposing roles in cardiac myocytes of the diabetic heart, where PPAR $\beta / \delta$ promotes glucose uptake, utilization, and overall cardiac health, while the PPAR $\alpha$ pathway decreases glucose utilization and promotes the myocardial lipid accumulation associated with cardiac disease (Burkart et al. 2007). PPAR $\gamma$ is strongly induced during adipocyte differentiation and its activity is necessary and, in some cases, sufficient for adipogenesis (Chawla \& Lazar 1994, Tontonoz et al. 1994, Tontonoz \& Spiegelman 2008). Two isoforms, $\gamma 1$ and $\gamma 2$, identical except for an additional 30 amino acids at the N-terminus of $\gamma 2$, are highly expressed in adipocytes, while other cell types express comparatively lower levels of the $\gamma 1$ isoform (Tontonoz et al. 1994, Nagy et al. 2013). Loss of PPAR $\gamma$ expression causes lipodystrophy in mice as do dominant negative mutants of PPAR $\gamma$ in both mice and humans (Barak et al. 2002, Freedman et al. 2005, Semple 2006, Duan et al. 2007). PPAR $\gamma$ also regulates lipid metabolism in macrophages and appears to have an overlapping but non-redundant role with PPAR $\delta$ in the regulation of macrophage polarization and homeostatic scavenging of apoptotic cells (Ahmadian et al. 2013).
PPARs bind DNA as obligate heterodimers with $\mathrm{Nr} 2 \mathrm{~b} 1$ (Rxr) family members to a direct repeat (DR) of the sequence AGGTCA separated by one nucleotide, usually an adenine (Kliewer et al. 1992b, IJpenberg et al. 1997, Varga et al. 2011). This DR1 element was initially defined using in vitro binding and transactivation assays and has been confirmed as the predominant recognition motif at PPAR binding sites identified on a genome-wide scale in vivo (Dreyer et al. 1992, Kliewer et al. 1992b, Tugwood et al. 1992, Lefterova et al. 2008, 2010, Nielsen et al. 2008, Mikkelsen et al. 2010, Boergesen et al. 2012).

\section{It's about time: orphans of the NR1D group}

\section{Nr1d1/Rev-erb $\alpha$ and Nr1d2/Rev-erb $\beta$}

Rev-erb $\alpha$ was discovered as a coding sequence on the reverse strand of the $c$-erb $\alpha$ gene, which encodes a thyroid hormone receptor, and the identification of $\operatorname{Rev}-\operatorname{erb} \beta$ followed several years later (Lazar et al. 1989, Dumas et al. 1994, Forman et al. 1994, Retnakaran et al. 1994). Structurally, the Rev-erbs are unique among NRs because they lack a critical alpha-helix (H12) in the AF2 domain that mediates coactivator interaction, resulting in a conformation more suitable for corepressor recruitment (Renaud etal. 2000, Ramakrishnan \& Muscat 2006, Yin etal. 2010). Both Rev-erb $\alpha$ and Rev-erb $\beta$ act as receptors for heme, which binds within the classic NR LBP (Reinking et al. 2005, Raghuram et al. 2007, Yin et al. 2007, Burris 2008). Several synthetic agonists have been developed and show potential for modulating Rev-erb in vivo (Yin et al. 2010, Solt et al. 2012). Besides ligand binding, regulation of Rev-erb activity also occurs at the level of gene expression, posttranslational modifications, and protein-protein interactions (Yin et al. 2010, Chini et al. 2013). For example, Rev-erb expression in most tissues is circadian and is tightly controlled by the core circadian clock TFs, BMAL1 and CLOCK, as well as repressing its own transcription (Feng \& Lazar 2012). Furthermore, Rev-erb $\alpha$ is stabilized by GSK3 $\beta$ mediated phosphorylation that can be blocked by lithium exposure; in hippocampal neurons, oligophrenin 1 alters cellular localization of Rev-erb $\alpha$, blocking its repressive function (Valnegri et al. 2011, Feng \& Lazar 2012).

Acting as dedicated transcriptional repressors, both Rev-erbs bind to extended half-sites (AGGTCA) with an A/T-rich $5^{\prime}$ end (RORE), a sequence identical to that recognized by NR1F (ROR) orphan receptors but with opposing effects. Importantly, Rev-erb monomer's association with isolated ROREs is not sufficient for active transcriptional repression (although it can still compete

Published by Bioscientifica Ltd 
with ROR binding to the RORE); however, two neighboring monomeric Rev-erbs can cooperate to recruit corepressors to repress gene expression (Yin et al. 2010). Heme stabilizes the interaction with NCoR, augmenting repression of transcription and defining the Rev-erb group as ligand-stimulated transcriptional repressors (Pardee et al. 2009). Rev-erb $\alpha$ and $\beta$ also dimerize and function at a DR of their unique half-site spaced by two additional nucleotides (Rev-DR2; Yin et al. 2010).

The Rev-erbs have been implicated in a variety of physiological processes, including cerebellar development, osteoarthritis, adipogenesis, and mitochondria biogenesis, but the most well-known cellular function is to act as integrators of circadian rhythm and metabolic pathways (Chomez et al. 2000, Chaturvedi et al. 2006, Ramakrishnan \& Muscat 2006, Wang \& Lazar 2008, Yin et al. 2010, Woldt et al. 2013). Genome-wide studies have indicated that the cyclic expression and genomic presence of both Rev-erbs result in the proper rhythmic expression of circadian clock and lipid metabolism genes and underscoring the importance of this convergence, Rev-erb deficiency in the liver results in hepatic steatosis and dysregulation of the cell autonomous hepatic clock (Bugge et al. 2012, Cho et al. 2012). Recent work has also described that Rev-erbs represent a key link between the cellular clock and macrophage function, where they function cyclically to limit the expression of cytokines impacting responses to pathogens (Fontaine et al. 2008, Gibbs et al. 2012, Chandra et al. 2013, Lam et al. 2013).

\section{More time for discussion: orphans of the NR1F group}

\section{Nr1f1/Ror $\alpha, N r 1 f 2 / R o r \beta$, and Nr1f3/Ror $\gamma$}

The RAR-related orphan NRs comprise three structurally related orphan NRs with roles in retinal development, lipid and glucose homeostasis, atherosclerosis, carcinogenesis, circadian rhythm, bone formation, and immunity (Becker-André et al. 1993, Medvedev et al. 1996, Jetten 2009, Solt \& Burris 2012). Of particular note, $\mathrm{ROR} \alpha$ is required for cerebellar development, and ROR $\gamma$ plays a critical role in lymphoid cells (Hamilton et al. 1996, Kurebayashi et al. 2000, Ivanov et al. 2006, Solt \& Burris 2012).

RORs bind as monomers to the same RORE sequence bound by Rev-erbs and are described as constitutive activators, recruiting coactivators in absence of ligand (Jetten 2009). However, independent investigations have suggested that oxysterols and cholesterol derivatives act as agonist and inverse agonist ligands of ROR $\alpha$ and $\gamma$ (Kallen et al. 2002, Jin et al. 2010, Wang et al. 2010). In addition, retinoids and retinoic acid have been shown to antagonize the activity of ROR $\beta$ (Stehlin-Gaon et al. 2003). Despite the uncertainty surrounding endogenous ligand regulation of RORs, the generation of synthetic agonists and inverse agonists has great therapeutic promise, particularly in modulating the function of the ROR $\gamma$-t isoform in $\mathrm{T}_{\mathrm{H}} 17$ lymphocytes during autoimmunity (Yang et al. 2008, Huh et al. 2011, Solt et al. 2011).

Like other NRs, activity of RORs can be regulated by posttranslational modifications, including phosphorylation and sumoylation (Hwang et al. 2009, Onishi et al. 2009, Lee et al. 2010). Intriguingly, a 'methyl degron' sequence has been recently described in $\mathrm{ROR} \alpha$, making it the first non-histone substrate targeted by methyltransferases to regulate protein stability (Lee et al. 2012). Antagonism with other TFs also mediates ROR activity, demonstrated by the recent observation that $\mathrm{ROR} \gamma$ function is inhibited by direct interaction with Foxp3 (Ichiyama et al. 2008, Zhou et al. 2008). Furthermore, the ability of ROR $\alpha$ and Rev-erb $\alpha$ to bind to overlapping sites and counteract each other's activity at target genes has been demonstrated in the circadian control of Bmal1 and Rev-erb $\alpha$ expression (Guillaumond et al. 2005). In addition to direct transcriptional regulation at specific response elements, the transrepression of Wnt/ $\beta$-catenin-mediated gene activation has been reported (Lee et al. 2010). Furthermore supporting the DNA-binding independent functions of RORs, ROR $\alpha$ has been reported to bind and stabilize p53 protein and thereby indirectly regulate p53 target gene expression (Kim et al. 2011, Wang et al. 2012).

\section{Watching what they eat: orphans of the NR1H group}

\section{Nr1h2/Lxr $\beta, N r 1 h 3 / L x r \alpha$, and Nr1h4/Fxr $\alpha$}

The Nr1h family includes liver X receptors, LXR $\alpha$ and LXR $\beta$, and farnesol X receptors, FXR $\alpha$ and FXR $\beta$, although FXR $\beta$ is found in mice but not in humans (Moore et al. 2006). LXRs and FXRs have metabolically intertwined roles that converge on minimizing the buildup of cholesterol by responding to elevated levels of sterols and BAs respectively (Calkin \& Tontonoz 2012). Endogenous LXR ligands that have been reported include: 24(S), 25-epoxycholesterol in the liver, 24(S)-hydroxycholesterol in the brain, and 27-hydroxycholesterol in macrophages (Moore et al. 2006). Synthetic, high affinity pan-LXR

Published by Bioscientifica Ltd 
agonists are in wide experimental use. These compounds promote the cholesterol-lowering activity of LXRs, but this benefit is offset by activation of the SREBP1C pathway of de novo lipogenesis in the liver, which has hindered the advancement of LXR agonists as therapies for human metabolic disorders (Repa et al. 2000, Joseph et al. 2002, Tangirala et al. 2002, Levin et al. 2005). FXR was initially named based on its activation by very high concentrations of farnesol and its metabolites in vitro, but was later found to respond to physiological concentrations of BAs and is now widely viewed as a nuclear BA receptor and central regulator of BA homeostasis (Forman et al. 1995, Makishima et al. 1999, Parks et al. 1999, Wang et al. 1999). BAs vary in their affinity for FXR with the strongest agonist being the primary BA chenodeoxycholic acid (CDCA; Modica et al. 2010). Importantly, synthetic FXR agonists are efficacious in treating mouse models of cholestatic diseases (Moschetta et al. 2004).

Subtype and cell type-specific deletions of LXR have uncovered their roles in the regulation of whole-body cholesterol homeostasis. In atherosclerosis-prone mouse strains, LXR $\alpha$ is required for preventing cholesterol overload in several tissues including the liver, where LXR $\alpha$ activation cannot be compensated for by LXR $\beta$; macrophages, where it contributes equally with LXR $\beta$; and likely other tissues including adipose and intestine (Lehrke et al. 2005, Bradley et al. 2007, Hong et al. 2012, Zhang et al. 2012). Similarly, LXR $\beta$ has a non-redundant role in preventing cholesterol accumulation in BA-metabolizing cholangiocytes, the CNS, spinal cord, and male gonadal cells (Gabbi et al. 2009, Xia et al. 2012). For FXR, activation by BAs initiates a negative feedback loop that limits BA synthesis and promotes their transit from hepatocytes to the enterohepatic circulation. Consistent with this, FXR-deficient mice challenged with high levels of dietary BAs suffer severe hepatotoxicity (Sinal et al. 2000).

All Nr1h members heterodimerize with RXR and recent genome-wide binding studies have demonstrated widespread use of sequence motifs identified using older low-throughput methods. In liver, the vast majority of FXR-binding sites identified by ChIP-seq, contained an IR1 motif (inverted repeats of the canonical NR half site AGGTCA separated by one nucleotide) which was initially reported as the preferred motif for FXR-RXR heterodimers (Laffitte et al. 2000, Chong et al. 2010, Thomas et al. 2010). Similarly, genome-wide profiling confirmed co-occupancy of LXR-RXR at DR4 motifs, initially characterized almost 20 years ago (Willy et al. 1995, Boergesen et al. 2012).

\section{The defenders: orphans of the NR1I group}

\section{Nr1i2/Pxr and Nr1i3/Car}

The pregnane $\mathrm{X}$ receptor (PXR) and constitutive androstane receptor (CAR) play a key role in the body's defense against xenobiotics (foreign materials encountered in the environment). Mouse and human PXRs were discovered almost simultaneously, revealing PXR as a conserved, direct regulator of $C y p 3 a$ family enzymes important in xenobiotic and endobiotic metabolism (Bertilsson et al. 1998, Blumberg et al. 1998, Kliewer et al. 1998, Lehmann et al. 1998). PXR can bind structurally distinct ligands that range in size from 268 to $823 \mathrm{Da}$ and are highly speciesspecific, in accordance with the relatively low conservation of the PXR LBP among orthologs (Reschly \& Krasowski 2006). This diverse array of xenobiotics, dietary compounds, and endobiotics includes rifampicin, clotrimazole, phenobarbital, the herbal antidepressant St John's wort, HIV protease inhibitors, and BAs (Zhou et al. 2009, Tolson \& Wang 2010). Initial cloning of CAR reported its transcriptional activity in the absence of an exogenous ligand, leading to the name constitutive active receptor before androstanes were identified as inverse agonists (Baes et al. 1994, Forman et al. 1998). To date, many xenobiotic agonists have been identified with phenobarbital-like compounds being the most widely used to study CAR's function (Gao \& Xie 2010).

Both receptors induce phase I and II drug metabolizing enzymes in the liver and intestine (Tolson \& Wang 2010, Ihunnah et al. 2011). Though this activity is clearly beneficial, it can also enhance drug toxicity, such as during the PXR-mediated accumulation of toxic aspirin metabolites (Guo et al. 2004). Similarly, CAR deficiency is protective against hepatotoxicity caused by the breakdown of phenobarbital and related compounds (Wei et al. 2000). Roles of PXR and CAR in endobiotic metabolism have also come to light. PXR can promote BA excretion from the liver into the urine, which may explain the profound susceptibility of PXR-deficient mice to challenge with a high cholesterol-BA diet (Staudinger et al. 2001, Xie et al. 2001, Sonoda et al. 2005). Ligand-activated PXR can also suppress hepatic gluconeogenesis and fasting-induced FAO and has been implicated in the regulation of reverse cholesterol transport, steroid hormone synthesis, and the catabolism of androgen, bilirubins, and retinoic acid (Ihunnah et al. 2011). Ligandactivated CAR protects against diet-induced obesity and its related metabolic complications (Gao et al. 2009).

Ligand activation of both PXR and CAR induces cytoplasmic to nuclear shuttling that can be regulated by

Published by Bioscientifica Ltd 
phosphorylation (Squires et al. 2004, Pondugula et al. 2009). Once in the nucleus, PXR binds DNA as a heterodimer with RXR, predominantly at DR4 motifs, as revealed by recent genome-wide binding analysis in the liver (Kliewer et al. 1998, Cui et al. 2010). Notably, this study found no evidence for PXR binding to everted repeats (ER6 or ER8), as was previously reported (Kliewer et al. 2002). CAR also binds as an obligate heterodimer with RXR to DR4 motifs, but this preference has yet to be shown on a genome-wide scale (Kawamoto et al. 1999, Sueyoshi \& Negishi 2001).

\section{Arrested development: orphans of the NR2A group}

\section{$\mathrm{Nr2a} 1 / \mathrm{Hnf} \alpha$ and Nr2a2/Hnf $\gamma$}

The hepatocyte nuclear factors HNF $4 \alpha$ and HNF4 $\gamma$ are encoded by two distinct but highly homologous genes (Drewes et al. 1996). Cloning of HNF4 $\alpha$ from human liver revealed several variants regulated by alternative promoter usage and splicing (Chartier et al. 1994, Kritis et al. 1996). There are two predominant isoforms: the longer HNF4 $\alpha 1$ containing an additional $\mathrm{N}$-terminal AF1 domain expressed highly in liver, and the shorter HNF4 $\alpha 7$ expressed highly in the pancreas (Eeckhoute et al. 2003). HNF4 $\gamma$ was cloned from a human kidney cDNA library and an early report found it in the pancreas, liver, brain, and lung (Plengvidhya et al. 1999). HNF4 $\alpha$ appears to function as a ligandindependent, constitutively active receptor (Ruse et al. 2002). However, several crystal structures of purified LBDs identified fatty acids in its binding pocket and there is evidence that linoleic acid binds to HNF4 $\alpha$ in the livers of fed, but not fasted, mice (Dhe-Paganon et al. 2002, Wisely et al. 2002, Yuan et al. 2009).

Mutations in HNF4 $\alpha$ are associated with a rare form of early-onset, autosomal dominant diabetes called maturity onset diabetes of the young, and therefore $\mathrm{HNF} \alpha$ is considered a MODY1 gene (Yamagata et al. 1996, Navas et al. 1999). Mouse models have shown that it is required in the pancreas for glucose-stimulated insulin secretion and beta cell expansion (Gupta et al. 2005, 2007). HNF4 $\alpha$ has pleiotropic roles in other enterohepatic tissues, most prominently in the liver, where it is required for the maturation, maintenance, and differentiated functions of hepatocytes (Sladek et al. 1990, Chen et al. 1994b). Disruption of this program by hepatocyte-specific ablation of $\mathrm{HNF} 4 \alpha$ results in hepatomegaly, fatty liver, reduced serum cholesterol and TG, increased serum BAs, and premature death (Hayhurst et al. 2001). In intestinal epithelial cells, HNF $4 \alpha$ regulates fatty acid re-absorption and barrier function (Cattin et al. 2009, Frochot et al. 2012). Importantly, HNF $4 \alpha$ is required for endoderm formation during development and at multiple stages of liver maturation (Duncan 2003, Parviz et al. 2003). Less is known about the physiological roles of HNF4 $\gamma$, but it appears to be dispensable for embryogenesis. Rather, it promotes normal energy expenditure and locomoter activity (Gerdin et al. 2006).

HNF $4 \alpha$ can bind as a homodimer or as a heterodimer with HNF4 $\gamma$ to DR1 recognition motifs (Daigo et al. 2011, Fang et al. 2012). Although many other NRs bind the DR1, one specific half-site motif (CAAAGTCCA) is preferred by $\mathrm{HNF} 4 \alpha$ in vitro and in vivo, suggesting a mechanism underlying its distinct target gene networks and functions (Odom et al. 2004, Gupta et al. 2005, Fang et al. 2012).

\section{Partners for life: orphans of the NR2B group}

\section{Nr2b1/Rxr $a, N r 2 b 2 / R x r \beta$, and Nr2b3/Rxr $\gamma$}

The Nr2b family includes retinoid $X$ receptors, $R X R \alpha$, $\operatorname{RXR} \beta$, and $\operatorname{RXR} \gamma$. Cloning of $\operatorname{RXR} \alpha$ as a retinoic acid-responsive factor that shared modest homology with retinoic acid receptors (RARs) was followed shortly by identification of RXR $\beta$ and RXR $\gamma$ (Mangelsdorf et al. 1990, Rowe et al. 1991, Yu et al. 1991). RXRs dimerize with and strengthen the DNA-binding and transcriptional activity of other NRs, a list that now includes TR, RARs, VDR, PPARs, LXRs, FXR, PXR, CAR, NGFIB, and NURR1 (Yu et al. 1991, Kliewer et al. 1992a, Leid et al. 1992, Marks et al. 1992, Mark \& Chambon 2003). RXRs bind 9-cisretinoic acid with high affinity, and their heterodimer partners can be defined as 'permissive' or 'non-permissive' based on whether an RXR ligand activates the complex (Levin et al. 1992, Mangelsdorf et al. 1992, Lefebvre et al. 2010). The production of 9-cis-RA in vivo is controversial, but several specific and high affinity pharmacological ligands have been developed (Wolf 2006, Pérez et al. 2012).

Because of their wide array of binding partners, RXRs may have the most disparate biological roles of all NRs. For instance, RXR $\alpha$ ablation is embryonic lethal due to cardiac defects likely to result from its participation in complexes with RAR (Kastner et al. 1994, Sucov et al. 1994, Gruber et al. 1996). In the liver, where RXR $\alpha$ is the most abundant subtype, hepatocyte-specific deletion results in elevated serum triglycerides, serum cholesterol, and dramatic intolerance to a high cholesterol diet, likely via a loss of LXR, FXR, and possibly PXR and CAR activities (Mangelsdorf et al. 1992, Wan et al. 2000). Ablation of

Published by Bioscientifica Ltd 
RXR $\beta$ is lethal in some genetic backgrounds and it has a non-redundant role in spermatogenesis (Kastner et al. 1996). RXR $\gamma$ is not essential for development but appears to be important for proper sensitivity to thyroid hormone, as knock-out mice have increased metabolic activity, serum $\mathrm{T}_{4}$ and $\mathrm{TSH}$, and are resistant to diet-induced obesity (Brown et al. 2000, Haugen et al. 2004). It is also required in the CNS for proper functioning of cholinergic and dopaminergic pathways and for oligodendrocyte differentiation (Saga et al. 1999, Krzyzosiak et al. 2010, Huang et al. 2011). Compound mutants in RXR family members have been generated and have been comprehensively reviewed elsewhere (Mark et al. 2006).

Recent ChIP-seq studies have profiled the binding specificities of RXRs on a genome-wide scale, revealing extensive co-occupancy of RXRs with PPAR $\gamma$ in adipocytes and LXR in liver. These studies also reported substantial numbers of RXR-only binding sites, suggesting the likely cooperation of RXR with additional NR partners in these tissues (Nielsen et al. 2008, Boergesen et al. 2012). A similar study found $\mathrm{RXR} \alpha$ bound near $\sim 80 \%$ of genes expressed in the liver, though expression of only a small fraction were affected by hepatocyte-specific RXR $\alpha$ knockout, illustrating the challenge of elucidating the role of RXRs in tissue-specific regulatory networks (Zhan et al. 2012).

\section{What's in a name: orphans of the NR2C group}

\section{$\mathrm{Nr2c1/Tr2}$ and Nr2c2/Tr4}

Testicular orphan NR $2(\operatorname{Tr} 2)$ was originally identified by screening a human testis cDNA library for novel genes containing sequences similar to previously identified NR DBDs and the identification of related receptor $\operatorname{Tr} 4$ (Tak1) was reported a few years later (Chang et al. 1989, 1994, Hirose et al. 1994, Law et al. 1994, Lee et al. 2002). Tr2 and Tr4 display a widespread expression pattern in embryonic and adult tissues, suggesting pleiotropic physiological functions (Lee et al. 2002). Indeed, loss of function studies implicated TR4 in many diverse biological systems, including the CNS, reproduction, and metabolism (Kim et al. 2003, Chen et al. 2005b, Kang et al. 2011, Lin et al. 2012). Interestingly, mice lacking TR2 appeared normal suggesting that the $\mathrm{Nr} 2 \mathrm{c}$ group may function redundantly and this is supported by the dramatic defect in stem cell self-renewal, commitment, and differentiation observed in mice lacking both orphan NRs (Shyr et al. 2002a, 2009).

TR2 and 4 can bind to response elements consisting of a DR of the canonical NR half site (AGGTCA) with various types of spacing (DR1-5) and, consistent with this relatively promiscuous binding, part of the group's functions seems to be mediated by sharing or competing with other NRs for response elements (Lin et al. 1995, Yan et al. 1998, Xie et al. 2009a). Direct regulation of transcription appears to be dependent on homo- or heterodimerization between the $\mathrm{Nr} 2 \mathrm{c}$ group members (Lee et al. 1998, Zhou et al. 2011). In contrast, the analysis of TR4-enriched genomic regions obtained with ChIP-seq revealed no obvious DR element, suggesting that the genomic localization of NR2C members may be indirect (O'Geen et al. 2010). Consistent with this, several studies have reported interaction with and regulation of other NRs independent of NR2C binding to DNA (Hu et al. 2002, Shyr et al. 2002b, Mu \& Chang 2003).

To date, ligands for $\mathrm{Nr} 2 \mathrm{c}$ group members have not been described, although there is some evidence that they can be bound and activated by polyunsaturated fatty acids (Xie et al. 2009a). A recent crystal structure showed ligand-free TR4 to be in an autorepressed conformation that can be modulated by retinoid treatment introducing another potential ligand of the $\mathrm{Nr} 2 \mathrm{c}$ group (Zhou et al. 2011). Receptor phosphorylation, acetylation, and sumoylation status can also cause the exchange of corepressors and coactivators and thereby convert NR2C receptors from transcriptional repressors to activators and vice versa (Khan et al. 2005, Gupta et al. 2009, Xie et al. 2011). This is exemplified by the regulation of the Oct4 promoter in stem cells by TR2, where phosphorylation of the receptor causes repression of Oct4, a critical switch in the balance of pluriopotent cell self-renewal and differentiation (Gupta et al. 2008). In addition to posttranslational modification, the expression level of TR2/4 appears to be an important means of activity modulation and showing therapeutic promise, genetic overexpression of $\operatorname{Tr} 2 / \operatorname{Tr} 4$ in the erythroid lineage of a sickle cell disease model conferred enhanced expression of target gene fetal hemoglobin and alleviated disease symptoms (Campbell et al. 2011).

\section{Seeing is believing: orphans of the NR2E group}

\section{Nr2e1/Tlx and Nr2e3/Pnr}

Tlx is the vertebrate homologue of the Drosophila gene tailess (tll), which was characterized in 1990 (Gui et al. 2011). A screening for similar genes led to the photoreceptor $N R$ (PNR), making it the latest vertebrate NR to be described (Chen et al. 1999, Kobayashi et al. 1999). TLX and PNR negatively regulate target gene transcription as

Published by Bioscientifica Ltd 
monomers or homodimers, recruiting corepressors to the half sites or DR1 elements although there have been reports of gene activation as well (Chen et al. 2005a, Zhang et al. 2006, Sun et al. 2007, Yokoyama et al. 2008, Qu et al. 2010). Furthermore, a recent study has reported the ability of PNR to interact with and positively regulate p53 in a manner independent of PNR DNA-binding (Wen et al. 2012). While very little is known about the ligand dependency of the Nr2e group, activity of PNR and TLX is regulated by interaction with other NRs, posttranslational modification, alternative splicing, and miRNA targeting (Cheng et al. 2004, Wolkenberg et al. 2006, Onishi et al. 2009, Zhao et al. 2009, 2010, Shibata et al. 2011, Qin et al. 2013b).

In contrast to most orphan NRs, the Nr2e members have very specialized physiological roles limited mainly to the development of the rods and cones of the retina and CNS function (Gui et al. 2011, Forrest \& Swaroop 2012). The essential role for PNR in retinal development is reflected in its mutation being highly associated with enhanced S-cone syndrome, retinitis pigmentosa, and other retinopathy in humans (Forrest \& Swaroop 2012). Retinal degeneration also occurs in mice with either a spontaneous or targeted deletion (Forrest \& Swaroop 2012). TLX also functions in preventing retinal degeneration and in addition, mouse models have demonstrated a critical role in the development of the limbic system, where deletion leads to extreme aggression (Monaghan et al. 1997, Yu et al. 2000, Young et al. 2002). More recently, the essential role of TLX in maintaining adult neural stem cells in an undifferentiated, proliferative state has come to light and this cellular function has been reported to impact both spatial learning and brain tumor expansion, suggesting its potential as a therapeutic target (Shi et al. 2004, Liu et al. 2010, Zou et al. 2012).

\section{Leaders of the chicken dance: orphans of the NR2F group Nr2f1/Coup-tfl, Nr2f2/Coup-tflI, and Nr2f6/Ear2}

Chicken ovalbumin upstream promoting TF 1 (COUP-TFI) was identified as a long-sought after regulator of the chicken ovalubin gene (Wang et al. 1989). It, as well as ERBA-related protein 2 (EAR2), was originally described as the genes encoding proteins with homology to thyroid receptor, while COUP-TFII, a Nr2f member highly related to COUP-TFI, was identified in a later screen (Miyajima et al. 1988, Ritchie et al. 1990, Ladias \& Karathanasis 1991).
COUP-TFI and II bind as dimers to repress transcription via DR1 elements (Tsai \& Tsai 1997, Alfano et al. 2013). The COUP-TFs can also promiscuously recognize many other direct, inverted and everted NR half-site (AGGTCA) repeats, enabling them to compete with and antagonize the action of other NRs (Tsai \& Tsai 1997, Alfano et al. 2013). These receptors also have transpressive effects mediated by heterodimerization with other TFs or their partner RXR. EAR2 also appears to be a transcriptional repressor able to heterodimerize with other NRs including the COUP-TFs (Jonk et al. 1994, Zhu et al. 2000, Warnecke et al. 2005). For example, EAR2 was recently demonstrated to bind and inhibit the function of ROR $\gamma \mathrm{t}$ in $\mathrm{T}_{\mathrm{H}} 17$ lympocytes (Hermann-Kleiter et al. 2012). Despite the large body of evidence describing this family as transcriptional repressors, there have been some reports of NR2F-mediated gene activation but in vivo relevance of these findings has not been substantiated (Tsai \& Tsai 1997). To date, the $N r 2 f$ members remain as true orphan NRs, but in addition to their level of gene expression, activity of these TFs is regulated by posttranslational modifications including phosphorylation (Tsai \& Tsai 1997, Hermann-Kleiter et al. 2008).

The Nr2f group is widely expressed and loss of function models has been a key in the dissection of their many physiological roles (Lin et al. 2011). By influencing cellular processes including, survival, migration, fate determination, and differentiation, COUP-TFI and II have unique and essential functions in neural development and organogenesis respectively (Lin et al. 2011). However, they do share nearly identical DBDs and LBDs and recent analyses of mice deficient in both receptors have uncovered a redundant role in retinal development (Satoh et al. 2009, Tang et al. 2010). In addition to loss of function studies, genome-wide profiling of histone modifications and analyses of enhancer sequences predicted a role for both COUP-TFI and II in the phenotype of embryonic neural crest cells (NCC) which was further supported by knockdown experiments in human NCCs (Rada-Iglesias et al. 2012). Besides direct developmental roles, the NR2F receptors have recently been implicated as potential targets in cancer therapeutic intervention (Litchfield \& Klinge 2012). For example, overexpression of COUP-TFII results in the inhibition of SMAD4-mediated transactivation, which normally prevents cancer progression in prostate epithelium (Qin et al. 2013a). In contrast to COUP-TFI and II, much less is known about EAR2; however, knock-out mouse studies have suggested the roles in the CNS and immune system (Warnecke et al. 2005, Hermann-Kleiter et al. 2008).

Published by Bioscientifica Ltd 


\section{Lots of energy: orphans of the NR3B group}

\section{Nr3b1/Err $\alpha, \mathrm{Nr3b2/Err \beta}$, and Nr3b3/Err $\gamma$}

Estrogen-related receptors, $\alpha(\mathrm{ERR} \alpha)$ and $\beta(\mathrm{ERR} \beta)$ were discovered by screening libraries with a probe consisting of the sequence of the DBD of estrogen receptor (ER) and were the first orphan NRs to be discovered (Giguère et al. 1988, Deblois \& Giguère 2011). Nearly a decade later, ERR $\gamma$ was discovered as a gene deleted in a critical region of Usher syndrome, a genetic disorder resulting in hearing and vision loss, and subsequently described by two additional groups (Eudy et al. 1998, Hong et al. 1999, Heard et al. 2000). The ERRs are constitutive activators and crystal structure studies suggest that classic ligand binding modulation is unlikely due to an inaccessible LBP. However, the presence of certain inverse agonists are able to induce a conformational change favoring corepressor interaction (Kallen et al. 2007, Xie et al. $2009 b$ ). Although no endogenous ligand for the ERRs has been reported, many inverse agonists and antagonists have been described, including pesticides, synthetic and phyto-estrogens, and 4-hydroxytamoxifen (4-OHT), underscoring the notion of functional crosstalk between ERR and ER signaling (Coward et al. 2001, Tremblay et al. 2001a,b, Bonnelye \& Aubin 2013). Adding to this complexity, bisphenol $\mathrm{A}$, the synthetic estrogen and endocrine disruptor found in many plastics, binds ERR $\gamma$ and prevents 4-OHT-induced coactivator dissociation (Takayanagi et al. 2006). Posttranslational modifications including phosphorylation, acetylation, and sumoylation also influence ERR activity (Ariazi et al. 2007, Tremblay et al. 2008, Wilson et al. 2010). The constitutive activity of the ERR group is also negatively regulated by DAX1 and SHP (Sanyal et al. 2002, Uranishi et al. 2013). The ERRs all recognize an extended half-site termed the ERRE (TNAAGGTCA) as monomers, homodimers, or heterodimers (Dufour et al. 2007, Tremblay \& Giguère 2007). Although ERRs may also have affinity for classic estrogen and thyroid receptor elements in vitro, recent genome wide localization studies have suggested that the ERRE is the main site of ERR occupancy (Johnston et al. 1997, Vanacker et al. 1998, Dufour et al. 2007, Tremblay \& Giguère 2007).

$\mathrm{ERR} \alpha$ and ERR $\gamma$ are widely expressed and regulate genes that modulate cellular energy metabolism by directing mitochondrial biogenesis and function impacting a variety of tissues under various physiological stresses including bone, adipose, heart, immune cells, kidney, and liver, implicating them as important therapeutic targets in a variety of metabolic disorders (Tremblay \& Giguère 2007, Giguère 2008, Deblois \& Giguère 2011). In addition, ERRs have the potential to modulate cancer cell energy production and, recently, ERR $\gamma$ has been identified as a miRNA target in breast cancer cells, leading to a shift from oxidative to glycolytic metabolism (Eichner et al. 2010, Deblois \& Giguère 2013). ERR $\beta$ has emerged as a component of cell pluripotency, being a key target of both NANOG and GSK/TCF3 pathways that modulates the expression of genes important in self-renewal (Ivanova et al. 2006, Chen et al. 2008, Festuccia et al. 2012, Martello et al. 2012). ERR $\beta$ also functions during development of the placenta, retina, and endolymph of the inner ear and, and mutations have been linked to hearing loss in humans (Chen \& Nathans 2007, Collin et al. 2008, Onishi et al. 2010, Ben Saïd et al. 2011, Lee et al. 2011b).

\section{First to the party: orphans of the NR4A group}

\section{Nr4a1/Nur77, Nr4a2/Nurr1, and Nr4a3/Nor1}

The Nr4a group consists of three related genes with many names reflecting discovery by many different groups: Nur77 (Ngfi-b, Tr3, N10, Nak-1, St-59), Nurr1 (Rnr-1, Not, Tinur) and Nor1 (Tec, Minor, Chn) (Hazel et al. 1988, Milbrandt 1988, Chang et al. 1989, Ryseck et al. 1989, Nakai et al. 1990, Law et al. 1992, Scearce et al. 1993, Mages et al. 1994, Ohkura et al. 1994, Hedvat \& Irving 1995, Labelle et al. 1995, Clark et al. 1996, Chen \& Nathans 2007, Collin et al. 2008, Onishi et al. 2010, Ben Saïd et al. 2011, Lee et al. 2011b). Depending on cellular and signal context, these receptors can function uniquely or redundantly as developmental modulators or immediate early genes whose expression is rapidly induced by a variety of stimuli to control cellular proliferation, function, or death (Li et al. 2006, Maxwell \& Muscat 2006). Key roles for the NR4A receptors have been demonstrated in many cell types including neuronal, immune, hematopoietic, cancer, endocrine, and metabolic (Li et al. 2006, Maxwell \& Muscat 2006, Pei et al. 2006, Pearen \& Muscat 2010, Zhao \& Bruemmer 2010, Luo 2012, Mohan et al. 2012, van Tiel \& de Vries 2012).

Nr4a orphans harbor a unique LBD filled with bulky hydrophobic residues that is unlikely to accommodate a typical ligand (Baker et al. 2003, Wang et al. 2003). Furthermore, nonclassical coactivator interfaces have been described for these receptors (Wansa et al. 2002, Codina et al. 2004). Therefore, regulation of the NR4A receptor activity depends on gene expression, alternative splicing, posttranslational modification, interaction with other NRs, microRNA targeting, and cellular localization (Maruyama et al. 1998, Maxwell \& Muscat 2006, Malewicz

Published by Bioscientifica Ltd 
et al. 2011, McMorrow \& Murphy 2011, Yang et al. 2012, Li et al. 2013). It should be noted that despite the unique structure of the LBD, pharmacological agonists have been described including 1,1-bis(3-indolyl)-1-(p-anisyl)methane, anti-neoplastic and anti-inflammatory agent 6-mercaptopurine, and cytosporone B (Wansa et al. 2003, Chintharlapalli et al. 2005, Zhan et al. 2008).

NURR1, NUR77, and NOR1 can bind as monomers to half-site recognition motifs called the NBRE (AAAGGTCA), but they can also homodimerize or heterodimerize with each other and with RXR and bind NurRE, a DR element (Maruyama et al. 1998, Maxwell \& Muscat 2006). The importance of the transactivation function of the NR4A receptors has been demonstrated in vivo. For example, Nor1 is a gene component within chromosomal translocations that occur frequently in human extraskeletal myxoid sarcoma (Labelle et al. 1995, Clark et al. 1996). The oncogenic fusion protein product of this translocation is frequently a strong activation domain of another TF such as EWS linked to a full length NOR1 leading to misregulation of NOR1 gene targets (Filion \& Labelle 2012). Critical gene regulation by NR4A receptors is also exemplified by the direct regulation of tyrosine hydroxylase in neurons by NURR1 to maintain the dopaminergic phenotype which is hampered in Parkinson's disease and by obligatory direct regulation of Foxp3 by all three NR4A members acting redundantly during the development of regulatory $\mathrm{T}$ cells thereby preventing autoimmunity (Sakurada et al. 1999, Luo 2012, Sekiya et al. 2013). Like other NRs, transrepression by the NR4A group has been reported. Specifically, NURR1 in concert with the CoREST complex is able to dock on the p65 subunit of $\mathrm{NF} \kappa \mathrm{B}$ and drive its clearance from inflammatory target genes in astrocytes and microglia, providing an additional mechanism for the protective function of NURR1 in Parkinson's disease (Saijo et al. 2009). Finally, NUR77 and NOR1 play essential roles in apoptosis in many cells and there is mounting evidence that this is accomplished in a non-genomic manner by converting BCL-2 proteins into pro-apoptotic molecules at the mitochondria (Li et al. 2006, Mohan et al. 2012). Underscoring the potential impact of this finding, small peptide mimics of NUR77 have been designed successfully to induce cancer cell death (Kolluri et al. 2008).

\section{On steroids: orphans of the NR5A group}

\section{Nr5a1/Sf1 and Nr5a2/Lrh1}

Steroidogenic factor 1 (SF1) was discovered by Lala et al. (1992) as a major regulator of steroidogenic enzyme gene expression. Liver receptor homolog 1 (LRH-1) was cloned by several groups as a regulator of heptatitis virus and albumin gene expression (Tsukiyama et al. 1992, Becker-André et al. 1993, Galarneau et al. 1996, Li et al. 1998, Nitta et al. 1999). SF1 and LRH1 have large, hydrophobic LBPs (Schimmer \& White 2010). Initial studies reported stable active state conformations of both receptor LBDs without addition of an exogenous ligand (Desclozeaux et al. 2002, Sablin et al. 2003). However, in 2005, three groups discovered phospholipid species in the LBPs of SF1 and LRH1 purified from bacteria (Krylova et al. 2005, Li et al. 2005, Ortlund et al. 2005). Intriguingly, an unusual phosphatidylcholine species was identified as an LRH1 ligand that, when administered to WT, but not $L r h 1^{-/-}$mice, improved their glucose homeostasis and ameliorated hepatic steatosis during high fat diet feeding (Lee et al. 2011a).

SF1 and LRH1 are transcriptional activators that bind DNA as monomers recognizing consensus of AGGTCA sequences. An apparent preference for YCA (where $\mathrm{Y}$ is a pyrimidine) $5^{\prime}$ to the hexamer may be due to a C-terminal extension (CTE) of the DBD shared with other monomeric DNA-binding NRs (Wilson et al. 1993, Solomon et al. 2005). SF1 and LRH1 also contain an additional 20 amino acid extension after the CTE called the Ftz-f1 motif (after Drosophila Ftz-f1) that is unique to NR5A family members (Ingraham \& Redinbo 2005). Crystal structures revealed that this motif does not contact DNA but rather affects interactions with co-activating proteins (Solomon et al. 2005). Recent genome-wide profiling of SF1 binding in adrenocortical cells found the NR half site as its preferential motif, but did not find enrichment of the predicted $5^{\prime}$ pyrimidine, suggesting that it may not be required for SF1 binding to DNA in chromatin (Doghman et al. 2013).

SF1 is required for the differentiation of steroidogenic tissues, with homozygous null mice dying shortly after birth due to corticosteroid insufficiency (Luo et al. 1994, Sadovsky et al. 1995). SF1 function is also required for cell autonomously in pituitary gonadotropes, developing gonads and postnatal ovarian granulosa cells (Schimmer $\&$ White 2010). These mouse models of sexual maturation defects are important to human disease, as shown by the reproductive dysfunction in patients with naturally occurring SF1 mutations (El-Khairi \& Achermann 2012, Lalli et al. 2013). LRH1 is involved in the regulation of steroid, BA and cholesterol homeostasis, processes that are consistent with its restricted expression in the pancreas, liver, intestines, and ovaries (Fernandez-Marcos et al. 2011). Hepatocyte-specific deletion of LRH1 changes the composition of the BA pool, resulting in decreased

Published by Bioscientifica Ltd 
intestinal lipid absorption and BA recycling (Mataki et al. 2007, Lee et al. 2008). LRH1 has also been implicated in regulating glucose metabolism in the liver and proliferation in the intestine and pancreas (Schoonjans et al. 2005, Oosterveer et al. 2012). Intriguingly, GWAS studies have found a link between LRH1 SNPs and pancreatic cancer susceptibility (Petersen et al. 2010).

\section{The family jewel: orphans of the NR6A group}

\section{Nr6a1/Genf}

Germ cell nuclear factor (Gcnf, Rtr, Ncnf) is unique enough within the NR superfamily to be the only member of the NR6 subfamily (Hummelke \& Cooney 2001, Germain et al. 2006). Originally named because of its robust and restricted expression in the germ cells, GCNF lacks a classic AF2 domain and acts as a transcriptional repressor through ligand-independent interactions with corepressor complexes (Chen et al. 1994a, Hirose et al. 1995, Bauer et al. 1997, Hummelke \& Cooney 2001, Mullen et al. 2007). To date, a ligand for GCNF has not been identified, and its activity appears to be controlled by regulation of its gene expression (Heinzer et al. 1998, Gurtan et al. 2013, Krill et al. 2013, Wang et al. 2013). While recombinant GCNF forms homodimers upon binding to a DR of the classic NR half-site (AGGTCA) with no additional central nucleotides (DR0), endogenous DR0-bound GCNF exists as an oligomer in a DNA-dependent manner unlike that of typical NR dimerization (Gu et al. 2005b).

One of the direct targets of GCNF is Oct4, a core TF in the maintenance of embryonic stem cell pluriopotency (Fuhrmann et al. 2001). Indeed, loss of function studies in mice has demonstrated that the GCNF-mediated repression of Oct4 is essential for stem cell differentiation during embryogenesis (Chung et al. 2001, Gu et al. 2005a). The regulation of Oct4 and other pluriopotency factors makes GCNF an attractive target for therapeutic manipulation and biomarking in stem cells (Mullen et al. 2007, Akamatsu et al. 2009, Wang et al. 2013).

\section{Summary and future perspectives}

Advances in chemistry and molecular biology have led to an enormous accumulation of knowledge about the number, regulation, and function of orphan NRs over the past 25 years since their initial discovery. This review has attempted to provide a high-level overview of this progress, focusing on how each orphan was discovered, its regulation by ligand, and its regulation of gene expression in different tissues in health and disease. Much more is known about each orphan NR, and readers are encouraged to seek out additional information from the printed and virtual scientific literature.

Although the family is much grown up, current rapid progress in high throughput nucleotide sequencing, proteomics, metabolomics, and computational biology promises to lead to a more complete and integrated understanding of the orphan NRs and how they are regulated in different tissues, and what they regulate at many developmental stages, and in disease states. This approach is presently somewhat limited by the lack of adequate antibodies and data analysis pipelines, and by the added complexity of many orphan NRs playing critical roles in cell types that are minority components of heterogenous tissues. Technical advances in these areas will be critical for the discovery of novel therapeutic targets as well as strategies that avoid off target effects while maintaining beneficial actions.

Possibly the largest question still unanswered concerns the identification of the most relevant endogenous ligands for most, if not all, of the orphan NRs. Beginning shortly after the initial discovery of orphan NRs, the issue of whether they would all have endogenous ligands was hotly debated ('Do Orphan Receptors Have Ligands?', see www.sarahgreene.net/previous/hmsbeagle/html/content/03/cutedge/ overview.htm) and this question still remains. While endogenous and synthetic ligands have been discovered for many of the orphan NRs, others seem likely to be bona fide ligand-independent TFs, yet this is almost impossible to prove (Schupp \& Lazar 2010). Further, in most cases, there is not a consensus about the physiological role of putative endogenous ligands. This is in clear contrast with NR superfamily members that are receptors for hormones, where the hormones were discovered before the ligands and, in most cases, are produced by discrete endocrine organs such as the thyroid and adrenals, whose function is largely based on secretion of their cognate hormones.

Nevertheless, the identification of biological functions and ligands that activate the orphan NRs has yielded remarkable insight into dozens of diverse physiological processes, from embryonic stem cell self renewal and differentiation to inflammation, circadian rhythm, and metabolism. This has led to a more complete understanding of the mechanism of action for certain drug classes, the identification of targets mediating adverse effects of environmental pollutants, better strategies for the reprograming of pluripotent cells, and development of novel small molecules for the treatment of human disease. Further dissection of orphan NR networks, including their

Published by Bioscientifica Ltd 
mechanisms of action and the genes and cellular processes that they regulate, continues to have great potential to elucidate the molecular pathology of diseases as well as the underlying physiology, leading to safer, more specific, and more effective therapeutic strategies that are likely to be evident at the next orphan NR reunion.

\section{Declaration of interest}

The authors declare that there is no conflict of interest that could be perceived as prejudicing the impartiality of the review.

\section{Funding}

Work on orphan NRs in the Lazar lab is supported by NIH DK45586 and DK49780 and the Cox Institute for Medical Research.

\section{Acknowledgements}

This review encompasses an enormous area and the authors apologize that they were not able to cite all important papers on orphan NRs.

\section{References}

Ahmadian M, Suh JM, Hah N, Liddle C, Atkins AR, Downes M \& Evans RM 2013 PPAR $\gamma$ signaling and metabolism: the good, the bad and the future. Nature Medicine 19 557-566. (doi:10.1038/nm.3159)

Akamatsu W, DeVeale B, Okano H, Cooney AJ \& van der Kooy D 2009 Suppression of Oct4 by germ cell nuclear factor restricts pluripotency and promotes neural stem cell development in the early neural lineage. Journal of Neuroscience 29 2113-2124. (doi:10.1523/JNEUROSCI.452708.2009)

Alfano C, Magrinelli E, Harb K \& Studer M 2013 The nuclear receptors COUP-TF: a long-lasting experience in forebrain assembly. Cellular and Molecular Life Sciences [in press]. (doi:10.1007/s00018-013-1320-6)

Aranda A \& Pascual A 2001 Nuclear hormone receptors and gene expression. Physiological Reviews 81 1269-1304.

Ariazi EA, Kraus RJ, Farrell ML, Jordan VC \& Mertz JE 2007 Estrogen-related receptor $\alpha 1$ transcriptional activities are regulated in part via the ErbB2/HER2 signaling pathway. Molecular Cancer Research 5 71-85. (doi:10.1158/1541-7786.MCR-06-0227)

Baes M, Gulick T, Choi HS, Martinoli MG, Simha D \& Moore DD 1994 A new orphan member of the nuclear hormone receptor superfamily that interacts with a subset of retinoic acid response elements. Molecular and Cellular Biology 14 1544-1552.

Baker KD, Shewchuk LM, Kozlova T, Makishima M, Hassell A, Wisely B, Caravella JA, Lambert MH, Reinking JL, Krause H et al. 2003 The Drosophila orphan nuclear receptor DHR38 mediates an atypical ecdysteroid signaling pathway. Cell 113 731-742. (doi:10.1016/S00928674(03)00420-3)

Barak Y, Liao D, He W, Ong ES, Nelson MC, Olefsky JM, Boland R \& Evans RM 2002 Effects of peroxisome proliferator-activated receptor $\delta$ on placentation, adiposity, and colorectal cancer. PNAS 99 303-308. (doi:10.1073/pnas.012610299)

Bauer UM, Schneider-Hirsch S, Reinhardt S, Pauly T, Maus A, Wang F, Heiermann R, Rentrop M \& Maelicke A 1997 Neuronal cell nuclear factor - a nuclear receptor possibly involved in the control of neurogenesis and neuronal differentiation. European Journal of Biochemistry/FEBS 249 826-837. (doi:10.1111/j.1432-1033.1997.t01-100826.x)
Båvner A, Sanyal S, Gustafsson J-Å \& Treuter E 2005 Transcriptional corepression by SHP: molecular mechanisms and physiological consequences. Trends in Endocrinology and Metabolism 16 478-488. (doi:10.1016/j.tem.2005.10.005)

Becker-André M, André E \& DeLamarter JF 1993 Identification of nuclear receptor mRNAs by RT-PCR amplification of conserved zinc-finger motif sequences. Biochemical and Biophysical Research Communications 194 1371-1379. (doi:10.1006/bbrc.1993.1976)

Benoit G, Malewicz M \& Perlmann T 2004 Digging deep into the pockets of orphan nuclear receptors: insights from structural studies. Trends in Cell Biology 14 369-376. (doi:10.1016/j.tcb.2004.05.007)

Benoit G, Cooney A, Giguere V, Ingraham H, Lazar M, Muscat G, Perlmann T, Renaud J-P, Schwabe J, Sladek F et al. 2006 International Union of Pharmacology. LXVI. Orphan nuclear receptors. Pharmacological Reviews 58 798-836. (doi:10.1124/pr.58.4.10)

Ben Saïd M, Ayedi L, Mnejja M, Hakim B, Khalfallah A, Charfeddine I, Khifagi C, Turki K, Ayadi H, Benzina Z et al. 2011 A novel missense mutation in the ESRRB gene causes DFNB35 hearing loss in a Tunisian family. European Journal of Medical Genetics 54 e535-e541. (doi:10.1016/ j.ejmg.2011.06.008)

Bensinger SJ \& Tontonoz P 2008 Integration of metabolism and inflammation by lipid-activated nuclear receptors. Nature $\mathbf{4 5 4} 470-477$. (doi:10.1038/nature07202)

Bertilsson G, Heidrich J, Svensson K, Asman M, Jendeberg L, SydowBäckman M, Ohlsson R, Postlind H, Blomquist P \& Berkenstam A 1998 Identification of a human nuclear receptor defines a new signaling pathway for CYP3A induction. PNAS 95 12208-12213. (doi:10.1073/ pnas.95.21.12208)

Blumberg B, Sabbagh W Jr, Juguilon H, Bolado J Jr, van Meter CM, Ong ES \& Evans RM 1998 SXR, a novel steroid and xenobiotic-sensing nuclear receptor. Genes and Development 12 3195-3205. (doi:10.1101/gad.12. 20.3195)

Boergesen M, Pedersen TA, Gross B, van Heeringen SJ, Hagenbeek D, Bindesbøll C, Caron S, Lalloyer F, Steffensen KR, Nebb HI et al. 2012 Genome-wide profiling of liver $\mathrm{X}$ receptor, retinoid $\mathrm{X}$ receptor, and peroxisome proliferator-activated receptor $\alpha$ in mouse liver reveals extensive sharing of binding sites. Molecular and Cellular Biology 32 852-867. (doi:10.1128/MCB.06175-11)

Bonnelye E \& Aubin JE 2013 An energetic orphan in an endocrine tissue: revised perspective of the function of estrogen receptor-related receptor $\alpha$ in bone and cartilage. Journal of Bone and Mineral Research 28 225-233. (doi:10.1002/jbmr.1836)

Bradley MN, Hong C, Chen M, Joseph SB, Wilpitz DC, Wang X, Lusis AJ, Collins A, Hseuh WA, Collins JL et al. 2007 Ligand activation of LXR $\beta$ reverses atherosclerosis and cellular cholesterol overload in mice lacking LXR $\alpha$ and apoE. Journal of Clinical Investigation 117 2337-2346. (doi:10.1172/JCI31909)

Brown NS, Smart A, Sharma V, Brinkmeier ML, Greenlee L, Camper SA, Jensen DR, Eckel RH, Krezel W, Chambon P et al. 2000 Thyroid hormone resistance and increased metabolic rate in the RXR- $\gamma$ deficient mouse. Journal of Clinical Investigation 106 73-79. (doi:10.1172/JCI9422)

Bugge A, Feng D, Everett LJ, Briggs ER, Mullican SE, Wang F, Jager J \& Lazar MA 2012 Rev-erb $\alpha$ and Rev-erb $\beta$ coordinately protect the circadian clock and normal metabolic function. Genes and Development 26 657-667. (doi:10.1101/gad.186858.112)

Burkart EM, Sambandam N, Han X, Gross RW, Courtois M, Gierasch CM, Shoghi K, Welch MJ \& Kelly DP 2007 Nuclear receptors PPAR $\beta / \delta$ and PPAR $\alpha$ direct distinct metabolic regulatory programs in the mouse heart. Journal of Clinical Investigation 117 3930-3939. (doi:10.1172/JCI32578)

Burris TP 2008 Nuclear hormone receptors for heme: REV-ERB $\alpha$ and REVERB $\beta$ are ligand-regulated components of the mammalian clock. Molecular Endocrinology 22 1509-1520. (doi:10.1210/me.2007-0519)

Calkin AC \& Tontonoz P 2012 Transcriptional integration of metabolism by the nuclear sterol-activated receptors LXR and FXR. Nature Reviews. Molecular Cell Biology 13 213-224. (doi:10.1038/nrm3312) 
Campbell AD, Cui S, Shi L, Urbonya R, Mathias A, Bradley K, Bonsu KO, Douglas RR, Halford B, Schmidt L et al. 2011 Forced TR2/TR4 expression in sickle cell disease mice confers enhanced fetal hemoglobin synthesis and alleviated disease phenotypes. PNAS 108 18808-18813. (doi:10.1073/pnas.1104964108)

Cattin A-L, Le Beyec J, Barreau F, Saint-Just S, Houllier A, Gonzalez FJ, Robine S, Pinçon-Raymond M, Cardot P, Lacasa M et al. 2009 Hepatocyte nuclear factor $4 \alpha$, a key factor for homeostasis, cell architecture, and barrier function of the adult intestinal epithelium. Molecular and Cellular Biology 29 6294-6308. (doi:10.1128/ MCB.00939-09)

Chanda D, Park J-H \& Choi H-S 2008 Molecular basis of endocrine regulation by orphan nuclear receptor small heterodimer partner. Endocrine Journal 55 253-268. (doi:10.1507/endocrj.K07E-103)

Chandra V, Mahajan S, Saini A, Dkhar HK, Nanduri R, Raj EB, Kumar A \& Gupta P 2013 Human IL10 gene repression by Rev-erb $\alpha$ ameliorates Mycobacterium tuberculosis clearance. Journal of Biological Chemistry $\mathbf{2 8 8}$ 10692-10702. (doi:10.1074/jbc.M113.455915)

Chang C, Kokontis J, Liao SS \& Chang Y 1989 Isolation and characterization of human TR3 receptor: a member of steroid receptor superfamily. Journal of Steroid Biochemistry 34 391-395. (doi:10.1016/00224731(89)90114-3)

Chang C, Da Silva SL, Ideta R, Lee Y, Yeh S \& Burbach JP 1994 Human and rat TR4 orphan receptors specify a subclass of the steroid receptor superfamily. PNAS 91 6040-6044. (doi:10.1073/pnas.91.13.6040)

Chartier FL, Bossu JP, Laudet V, Fruchart JC \& Laine B 1994 Cloning and sequencing of cDNAs encoding the human hepatocyte nuclear factor 4 indicate the presence of two isoforms in human liver. Gene $\mathbf{1 4 7}$ 269-272. (doi:10.1016/0378-1119(94)90079-5)

Chaturvedi P, Pratta M, Steplewski K, Connor J \& Kumar S 2006 Functional characterization of an orphan nuclear receptor, Rev-ErbA $\alpha$, in chondrocytes and its potential role in osteoarthritis. Arthritis and Rheumatism 54 3513-3522. (doi:10.1002/art.22170)

Chawla A \& Lazar MA 1994 Peroxisome proliferator and retinoid signaling pathways co-regulate preadipocyte phenotype and survival. PNAS 91 1786-1790. (doi:10.1073/pnas.91.5.1786)

Chen J \& Nathans J 2007 Estrogen-related receptor $\beta /$ NR3B2 controls epithelial cell fate and endolymph production by the stria vascularis. Developmental Cell 13 325-337. (doi:10.1016/j.devcel.2007.07.011)

Chen F, Cooney AJ, Wang Y, Law SW \& O'Malley BW 1994a Cloning of a novel orphan receptor (GCNF) expressed during germ cell development. Molecular Endocrinology 8 1434-1444. (doi:10.1210/me.8.10. 1434)

Chen WS, Manova K, Weinstein DC, Duncan SA, Plump AS, Prezioso VR, Bachvarova RF \& Darnell JE 1994b Disruption of the HNF-4 gene, expressed in visceral endoderm, leads to cell death in embryonic ectoderm and impaired gastrulation of mouse embryos. Genes and Development 8 2466-2477. (doi:10.1101/gad.8.20.2466)

Chen F, Figueroa DJ, Marmorstein AD, Zhang Q, Petrukhin K, Caskey CT \& Austin CP 1999 Retina-specific nuclear receptor: a potential regulator of cellular retinaldehyde-binding protein expressed in retinal pigment epithelium and Müller glial cells. PNAS 96 15149-15154. (doi:10.1073/ pnas.96.26.15149)

Chen J, Rattner A \& Nathans J 2005a The rod photoreceptor-specific nuclear receptor $\mathrm{Nr} 2 \mathrm{e} 3$ represses transcription of multiple cone-specific genes. Journal of Neuroscience 25 118-129. (doi:10.1523/JNEUROSCI. 3571-04.2005)

Chen Y-T, Collins LL, Uno H \& Chang C 2005 $b$ Deficits in motor coordination with aberrant cerebellar development in mice lacking testicular orphan nuclear receptor 4. Molecular and Cellular Biology 25 2722-2732. (doi:10.1128/MCB.25.7.2722-2732.2005)

Chen X, Xu H, Yuan P, Fang F, Huss M, Vega VB, Wong E, Orlov YL, Zhang W, Jiang J et al. 2008 Integration of external signaling pathways with the core transcriptional network in embryonic stem cells. Cell $\mathbf{1 3 3}$ 1106-1117. (doi:10.1016/j.cell.2008.04.043)
Cheng H, Khanna H, Oh ECT, Hicks D, Mitton KP \& Swaroop A 2004 Photoreceptor-specific nuclear receptor NR2E3 functions as a transcriptional activator in rod photoreceptors. Human Molecular Genetics 13 1563-1575. (doi:10.1093/hmg/ddh173)

Chini CCS, Escande C, Nin V \& Chini EN 2013 DBC1 (deleted in breast cancer 1) modulates the stability and function of the nuclear receptor Rev-erb $\alpha$. Biochemical Journal 451 453-461. (doi:10.1042/BJ20121085)

Chintharlapalli S, Burghardt R, Papineni S, Ramaiah S, Yoon K \& Safe S 2005 Activation of Nur77 by selected 1,1-bis(3'-indolyl)-1-(p-substituted phenyl)methanes induces apoptosis through nuclear pathways. Journal of Biological Chemistry 280 24903-24914. (doi:10.1074/jbc. M500107200)

Cho H, Zhao X, Hatori M, Yu RT, Barish GD, Lam MT, Chong L-W, DiTacchio L, Atkins AR, Glass CK et al. 2012 Regulation of circadian behaviour and metabolism by REV-ERB- $\alpha$ and REV-ERB- $\beta$. Nature $\mathbf{4 8 5}$ 123-127. (doi:10.1038/nature11048)

Chomez P, Neveu I, Mansén A, Kiesler E, Larsson L, Vennström B \& Arenas E 2000 Increased cell death and delayed development in the cerebellum of mice lacking the rev-erbA( $\alpha$ ) orphan receptor. Development 127 1489-1498.

Chong HK, Infante AM, Seo Y-K, Jeon T-I, Zhang Y, Edwards PA, Xie X \& Osborne TF 2010 Genome-wide interrogation of hepatic FXR reveals an asymmetric IR-1 motif and synergy with LRH-1. Nucleic Acids Research 38 6007-6017. (doi:10.1093/nar/gkq397)

Chung AC, Katz D, Pereira FA, Jackson KJ, DeMayo FJ, Cooney AJ \& O'Malley BW 2001 Loss of orphan receptor germ cell nuclear factor function results in ectopic development of the tail bud and a novel posterior truncation. Molecular and Cellular Biology 21 663-677. (doi:10.1128/MCB.21.2.663-677.2001)

Clark J, Benjamin H, Gill S, Sidhar S, Goodwin G, Crew J, Gusterson BA Shipley J \& Cooper CS 1996 Fusion of the EWS gene to CHN, a member of the steroid/thyroid receptor gene superfamily, in a human myxoid chondrosarcoma. Oncogene 12 229-235.

Codina A, Benoit G, Gooch JT, Neuhaus D, Perlmann T \& Schwabe JWR 2004 Identification of a novel co-regulator interaction surface on the ligand binding domain of Nurr1 using NMR footprinting. Journal of Biological Chemistry 279 53338-53345. (doi:10.1074/jbc.M409096200)

Collin RWJ, Kalay E, Tariq M, Peters T, van der Zwaag B, Venselaar H, Oostrik J, Lee K, Ahmed ZM, Caylan R et al. 2008 Mutations of ESRRB encoding estrogen-related receptor $\beta$ cause autosomal-recessive nonsyndromic hearing impairment DFNB35. American Journal of Human Genetics 82 125-138. (doi:10.1016/j.ajhg.2007.09.008)

Coward P, Lee D, Hull MV \& Lehmann JM 2001 4-Hydroxytamoxifen binds to and deactivates the estrogen-related receptor $\gamma$. PNAS 98 8880-8884. (doi:10.1073/pnas.151244398)

Cui JY, Gunewardena SS, Rockwell CE \& Klaassen CD 2010 ChIPing the cistrome of PXR in mouse liver. Nucleic Acids Research 38 7943-7963. (doi:10.1093/nar/gkq654)

Daigo K, Kawamura T, Ohta Y, Ohashi R, Katayose S, Tanaka T, Aburatani H, Naito M, Kodama T, Ihara S et al. 2011 Proteomic analysis of native hepatocyte nuclear factor- $4 \alpha$ (HNF4 $\alpha$ ) isoforms, phosphorylation status, and interactive cofactors. Journal of Biological Chemistry 286 674-686. (doi:10.1074/jbc.M110.154732)

Deblois G \& Giguère V 2011 Functional and physiological genomics of estrogen-related receptors (ERRs) in health and disease. Biochimica et Biophysica Acta 1812 1032-1040. (doi:10.1016/j.bbadis.2010.12.009)

Deblois G \& Giguère V 2013 Oestrogen-related receptors in breast cancer: control of cellular metabolism and beyond. Nature Reviews. Cancer 13 27-36. (doi:10.1038/nrc3396)

Desclozeaux M, Krylova IN, Horn F, Fletterick RJ \& Ingraham HA 2002 Phosphorylation and intramolecular stabilization of the ligand binding domain in the nuclear receptor steroidogenic factor 1. Molecular and Cellular Biology 22 7193-7203. (doi:10.1128/МСB.22.20.7193-7203. 2002)

Dhe-Paganon S, Duda K, Iwamoto M, Chi Y-I \& Shoelson SE 2002 Crystal structure of the HNF4 $\alpha$ ligand binding domain in complex with 
endogenous fatty acid ligand. Journal of Biological Chemistry $\mathbf{2 7 7}$ 37973-37976. (doi:10.1074/jbc.C200420200)

Doghman M, Figueiredo BC, Volante M, Papotti M \& Lalli E 2013 Integrative analysis of SF-1 transcription factor dosage impact on genome-wide binding and gene expression regulation. Nucleic Acids Research 41 8896-8907. (doi:10.1093/nar/gkt658)

Drewes T, Senkel S, Holewa B \& Ryffel GU 1996 Human hepatocyte nuclear factor 4 isoforms are encoded by distinct and differentially expressed genes. Molecular and Cellular Biology 16 925-931.

Dreyer C, Krey G, Keller H, Givel F, Helftenbein G \& Wahli W 1992 Control of the peroxisomal $\beta$-oxidation pathway by a novel family of nuclear hormone receptors. Cell 68 879-887. (doi:10.1016/00928674(92)90031-7)

Duan SZ, Ivashchenko CY, Whitesall SE, D'Alecy LG, Duquaine DC, Brosius FC III, Gonzalez FJ, Vinson C, Pierre MA, Milstone DS et al. 2007 Hypotension, lipodystrophy, and insulin resistance in generalized PPAR $\gamma$-deficient mice rescued from embryonic lethality. Journal of Clinical Investigation 117 812-822. (doi:10.1172/JCI28859)

Dufour CR, Wilson BJ, Huss JM, Kelly DP, Alaynick WA, Downes M, Evans RM, Blanchette M \& Giguère V 2007 Genome-wide orchestration of cardiac functions by the orphan nuclear receptors ERR $\alpha$ and $\gamma$. Cell Metabolism 5 345-356. (doi:10.1016/j.cmet.2007.03.007)

Dumas B, Harding HP, Choi HS, Lehmann KA, Chung M, Lazar MA \& Moore DD 1994 A new orphan member of the nuclear hormone receptor superfamily closely related to Rev-Erb. Molecular Endocrinology 8 996-1005. (doi:10.1210/me.8.8.996)

Duncan SA 2003 Mechanisms controlling early development of the liver Mechanisms of Development 120 19-33. (doi:10.1016/S09254773(02)00328-3)

Eeckhoute J, Moerman E, Bouckenooghe T, Lukoviak B, Pattou F, Formstecher P, Kerr-Conte J, Vandewalle B \& Laine B 2003 Hepatocyte nuclear factor $4 \alpha$ isoforms originated from the P1 promoter are expressed in human pancreatic $\beta$-cells and exhibit stronger transcriptional potentials than P2 promoter-driven isoforms. Endocrinology 144 1686-1694. (doi:10.1210/en.2002-0024)

Ehrlund A \& Treuter E 2012 Ligand-independent actions of the orphan receptors/corepressors DAX-1 and SHP in metabolism, reproduction and disease. Journal of Steroid Biochemistry and Molecular Biology 130 169-179. (doi:10.1016/j.jsbmb.2011.04.007)

Eichner LJ, Perry M-C, Dufour CR, Bertos N, Park M, St-Pierre J \& Giguère V 2010 miR-378 (*) mediates metabolic shift in breast cancer cells via the PGC-1ß/ERR $\gamma$ transcriptional pathway. Cell Metabolism 12 352-361. (doi:10.1016/j.cmet.2010.09.002)

El-Khairi R \& Achermann JC 2012 Steroidogenic factor-1 and human disease. Seminars in Reproductive Medicine 30 374-381. (doi:10.1055/ s-0032-1324720)

Eudy JD, Yao S, Weston MD, Ma-Edmonds M, Talmadge CB, Cheng JJ, Kimberling WJ \& Sumegi J 1998 Isolation of a gene encoding a novel member of the nuclear receptor superfamily from the critical region of Usher syndrome type IIa at 1q41. Genomics 50 382-384. (doi:10.1006/ geno.1998.5345)

Evans RM, Barish GD \& Wang Y-X 2004 PPARs and the complex journey to obesity. Nature Medicine 10 355-361. (doi:10.1038/nm1025)

Fahrbach SE, Smagghe G \& Velarde RA 2012 Insect nuclear receptors. Annual Review of Entomology 57 83-106. (doi:10.1146/annurevento-120710-100607)

Fang B, Mane-Padros D, Bolotin E, Jiang T \& Sladek FM 2012 Identification of a binding motif specific to HNF4 by comparative analysis of multiple nuclear receptors. Nucleic Acids Research 40 5343-5356. (doi:10.1093/nar/gks190)

Feng D \& Lazar MA 2012 Clocks, metabolism, and the epigenome. Molecular Cell 47 158-167. (doi:10.1016/j.molcel.2012.06.026)

Fernandez-Marcos PJ, Auwerx J \& Schoonjans K 2011 Emerging actions of the nuclear receptor LRH-1 in the gut. Biochimica et Biophysica Acta 1812 947-955. (doi:10.1016/j.bbadis.2010.12.010)

Festuccia N, Osorno R, Halbritter F, Karwacki-Neisius V, Navarro P, Colby D, Wong F, Yates A, Tomlinson SR \& Chambers I 2012 Esrrb is a direct Nanog target gene that can substitute for Nanog function in pluripotent cells. Cell Stem Cell 11 477-490. (doi:10.1016/j.stem.2012.08.002)

Filion C \& Labelle Y 2012 Identification of genes regulated by the EWS/NR4A3 fusion protein in extraskeletal myxoid chondrosarcoma. Tumour Biology 33 1599-1605. (doi:10.1007/s13277-012-0415-2)

Fontaine C, Rigamonti E, Pourcet B, Duez H, Duhem C, Fruchart J-C, Chinetti-Gbaguidi G \& Staels B 2008 The nuclear receptor Rev-erb $\alpha$ is a liver X receptor (LXR) target gene driving a negative feedback loop on select LXR-induced pathways in human macrophages. Molecular Endocrinology 22 1797-1811. (doi:10.1210/me.2007-0439)

Forman BM, Chen J, Blumberg B, Kliewer SA, Henshaw R, Ong ES \& Evans RM 1994 Cross-talk among ROR $\alpha 1$ and the Rev-erb family of orphan nuclear receptors. Molecular Endocrinology 8 1253-1261. (doi:10.1210/me.8.9.1253)

Forman BM, Umesono K, Chen J \& Evans RM 1995 Unique response pathways are established by allosteric interactions among nuclear hormone receptors. Cell 81 541-550. (doi:10.1016/00928674(95)90075-6)

Forman BM, Tzameli I, Choi HS, Chen J, Simha D, Seol W, Evans RM \& Moore DD 1998 Androstane metabolites bind to and deactivate the nuclear receptor CAR- $\beta$. Nature 395 612-615. (doi:10.1038/26996)

Forrest D \& Swaroop A 2012 Minireview: the role of nuclear receptors in photoreceptor differentiation and disease. Molecular Endocrinology 26 905-915. (doi:10.1210/me.2012-1010)

Freedman BD, Lee E-J, Park Y \& Jameson JL 2005 A dominant negative peroxisome proliferator-activated receptor- $\gamma$ knock-in mouse exhibits features of the metabolic syndrome. Journal of Biological Chemistry $\mathbf{2 8 0}$ 17118-17125. (doi:10.1074/jbc.M407539200)

Frochot V, Alqub M, Cattin A-L, Carrière V, Houllier A, Baraille F, Barbot L, Saint-Just S, Ribeiro A, Lacasa M et al. 2012 The transcription factor HNF-4 $\alpha$ : a key factor of the intestinal uptake of fatty acids in mouse. American Journal of Physiology. Gastrointestinal and Liver Physiology $\mathbf{3 0 2}$ G1253-G1263. (doi:10.1152/ajpgi.00329.2011)

Fuhrmann G, Chung AC, Jackson KJ, Hummelke G, Baniahmad A, Sutter J, Sylvester I, Schöler HR \& Cooney AJ 2001 Mouse germline restriction of Oct4 expression by germ cell nuclear factor. Developmental Cell $\mathbf{1}$ 377-387. (doi:10.1016/S1534-5807(01)00038-7)

Gabbi C, Warner M \& Gustafsson J-A 2009 Minireview: liver X receptor $\beta$ : emerging roles in physiology and diseases. Molecular Endocrinology 23 129-136. (doi:10.1210/me.2008-0398)

Galarneau L, Paré JF, Allard D, Hamel D, Levesque L, Tugwood JD, Green S \& Bélanger L 1996 The $\alpha 1$-fetoprotein locus is activated by a nuclear receptor of the Drosophila FTZ-F1 family. Molecular and Cellular Biology $163853-3865$

Gao J, He J, Zhai Y, Wada T \& Xie W 2009 The constitutive androstane receptor is an anti-obesity nuclear receptor that improves insulin sensitivity. Journal of Biological Chemistry 284 25984-25992. (doi:10. 1074/jbc.M109.016808)

Gao J \& Xie W 2010 Pregnane X receptor and constitutive androstane receptor at the crossroads of drug metabolism and energy metabolism. Drug Metabolism and Disposition 38 2091-2095. (doi:10.1124/dmd.110. 035568)

Gerdin AK, Surve VV, Jönsson M, Bjursell M, Björkman M, Edenro A, Schuelke M, Saad A, Bjurström S, Lundgren EJ et al. 2006 Phenotypic screening of hepatocyte nuclear factor (HNF) $4-\gamma$ receptor knockout mice. Biochemical and Biophysical Research Communications 349 825-832. (doi:10.1016/j.bbrc.2006.08.103)

Germain P, Staels B, Dacquet C, Spedding M \& Laudet V 2006 Overview of nomenclature of nuclear receptors. Pharmacological Reviews $\mathbf{5 8}$ 685-704. (doi:10.1124/pr.58.4.2)

Gibbs JE, Blaikley J, Beesley S, Matthews L, Simpson KD, Boyce SH, Farrow SN, Else KJ, Singh D, Ray DW et al. 2012 The nuclear receptor REV-ERB $\alpha$ mediates circadian regulation of innate immunity through selective regulation of inflammatory cytokines. PNAS 109 582-587. (doi:10.1073/pnas.1106750109) 
Giguère V 1999 Orphan nuclear receptors: from gene to function. Endocrine Reviews 20 689-725. (doi:10.1210/er.20.5.689)

Giguère V 2008 Transcriptional control of energy homeostasis by the estrogen-related receptors. Endocrine Reviews 29 677-696. (doi:10.1210/ er.2008-0017)

Giguère V, Yang N, Segui P \& Evans RM 1988 Identification of a new class of steroid hormone receptors. Nature 331 91-94. (doi:10.1038/331091a0)

Gruber PJ, Kubalak SW, Pexieder T, Sucov HM, Evans RM \& Chien KR 1996 $\mathrm{RXR} \alpha$ deficiency confers genetic susceptibility for aortic sac, conotruncal, atrioventricular cushion, and ventricular muscle defects in mice. Journal of Clinical Investigation 98 1332-1343. (doi:10.1172/ JCI118920)

Gu P, LeMenuet D, Chung AC-K, Mancini M, Wheeler DA \& Cooney AJ $2005 a$ Orphan nuclear receptor GCNF is required for the repression of pluripotency genes during retinoic acid-induced embryonic stem cell differentiation. Molecular and Cellular Biology 25 8507-8519. (doi:10.1128/MCB.25.19.8507-8519.2005)

Gu P, Morgan DH, Sattar M, Xu X, Wagner R, Raviscioni M, Lichtarge O \& Cooney AJ $2005 b$ Evolutionary trace-based peptides identify a novel asymmetric interaction that mediates oligomerization in nuclear receptors. Journal of Biological Chemistry $28031818-31829$. (doi:10.1074/jbc.M501924200)

Gui H, Li M-L \& Tsai C-C 2011 A tale of tailless. Developmental Neuroscience 33 1-13. (doi:10.1159/000321585)

Guillaumond F, Dardente H, Giguère V \& Cermakian N 2005 Differential control of Bmal1 circadian transcription by REV-ERB and ROR nuclear receptors. Journal of Biological Rhythms 20 391-403. (doi:10.1177/0748730405277232)

Guo GL, Moffit JS, Nicol CJ, Ward JM, Aleksunes LA, Slitt AL, Kliewer SA Manautou JE \& Gonzalez FJ 2004 Enhanced acetaminophen toxicity by activation of the pregnane X receptor. Toxicological Sciences 82 374-380. (doi:10.1093/toxsci/kfh286)

Gupta RK, Vatamaniuk MZ, Lee CS, Flaschen RC, Fulmer JT, Matschinsky FM, Duncan SA \& Kaestner KH 2005 The MODY1 gene $\mathrm{HNF}-4 \alpha$ regulates selected genes involved in insulin secretion. Journal of Clinical Investigation 115 1006-1015. (doi:10.1172/ JCI22365)

Gupta RK, Gao N, Gorski RK, White P, Hardy OT, Rafiq K, Brestelli JE, Chen G, Stoeckert CJ Jr \& Kaestner KH 2007 Expansion of adult $\beta$-cell mass in response to increased metabolic demand is dependent on HNF- $4 \alpha$. Genes and Development 21 756-769. (doi:10.1101/gad.1535507)

Gupta P, Ho P-C, Huq MM, Ha SG, Park SW, Khan AA, Tsai N-P \& Wei L-N 2008 Retinoic acid-stimulated sequential phosphorylation, PML recruitment, and SUMOylation of nuclear receptor TR2 to suppress Oct4 expression. PNAS 105 11424-11429. (doi:10.1073/pnas. 0710561105)

Gupta P, Ho P-C, Ha SG, Lin Y-W \& Wei L-N 2009 HDAC3 as a molecular chaperone for shuttling phosphorylated TR2 to PML: a novel deacetylase activity-independent function of HDAC3. PLOS ONE $\mathbf{4}$ e4363. (doi:10.1371/journal.pone.0004363)

Gurtan AM, Ravi A, Rahl PB, Bosson AD, JnBaptiste CK, Bhutkar A, Whittaker CA, Young RA \& Sharp PA 2013 Let-7 represses Nr6a1 and a mid-gestation developmental program in adult fibroblasts. Genes and Development 27 941-954. (doi:10.1101/gad.215376.113)

Hamilton BA, Frankel WN, Kerrebrock AW, Hawkins TL, FitzHugh W, Kusumi K, Russell LB, Mueller KL, van Berkel V, Birren BW et al. 1996 Disruption of the nuclear hormone receptor ROR $\alpha$ in staggerer mice. Nature 379 736-739. (doi:10.1038/379736a0)

Haugen BR, Jensen DR, Sharma V, Pulawa LK, Hays WR, Krezel W, Chambon P \& Eckel RH 2004 Retinoid X receptor $\gamma$-deficient mice have increased skeletal muscle lipoprotein lipase activity and less weight gain when fed a high-fat diet. Endocrinology 145 3679-3685. (doi:10. 1210/en.2003-1401)

Hayhurst GP, Lee Y-H, Lambert G, Ward JM \& Gonzalez FJ 2001 Hepatocyte nuclear factor $4 \alpha$ (nuclear receptor $2 \mathrm{~A} 1$ ) is essential for maintenance of hepatic gene expression and lipid homeostasis. Molecular and Cellular Biology 21 1393-1403. (doi:10.1128/MCB.21.4.1393-1403.2001)

Hazel TG, Nathans D \& Lau LF 1988 A gene inducible by serum growth factors encodes a member of the steroid and thyroid hormone receptor superfamily. PNAS 85 8444-8448. (doi:10.1073/pnas.85.22.8444)

Heard DJ, Norby PL, Holloway J \& Vissing H 2000 Human ERR $\gamma$, a third member of the estrogen receptor-related receptor (ERR) subfamily of orphan nuclear receptors: tissue-specific isoforms are expressed during development and in the adult. Molecular Endocrinology 14 382-392. (doi:10.1210/me.14.3.382)

Hedvat CV \& Irving SG 1995 The isolation and characterization of MINOR, a novel mitogen-inducible nuclear orphan receptor. Molecular Endocrinology 9 1692-1700. (doi:10.1210/me.9.12.1692)

Heinzer C, Süsens U, Schmitz TP \& Borgmeyer U 1998 Retinoids induce differential expression and DNA binding of the mouse germ cell nuclear factor in P19 embryonal carcinoma cells. Biological Chemistry 379 349-359. (doi:10.1515/bchm.1998.379.3.349)

Helsen C, Kerkhofs S, Clinckemalie L, Spans L, Laurent M, Boonen S, Vanderschueren D \& Claessens F 2012 Structural basis for nuclear hormone receptor DNA binding. Molecular and Cellular Endocrinology 348 411-417. (doi:10.1016/j.mce.2011.07.025)

Hermann-Kleiter N, Gruber T, Lutz-Nicoladoni C, Thuille N, Fresser F, Labi V, Schiefermeier N, Warnecke M, Huber L, Villunger A et al. 2008 The nuclear orphan receptor NR2F6 suppresses lymphocyte activation and T helper 17-dependent autoimmunity. Immunity 29 205-216. (doi:10.1016/j.immuni.2008.06.008)

Hermann-Kleiter N, Meisel M, Fresser F, Thuille N, Müller M, Roth L, Katopodis A \& Baier G 2012 Nuclear orphan receptor NR2F6 directly antagonizes NFAT and ROR $\gamma$ t binding to the Il17a promoter. Journal of Autoimmunity 39 428-440. (doi:10.1016/j.jaut.2012.07.007)

Hirose T, Fujimoto W, Tamaai T, Kim KH, Matsuura H \& Jetten AM 1994 TAK1: molecular cloning and characterization of a new member of the nuclear receptor superfamily. Molecular Endocrinology 8 1667-1680. (doi:10.1210/me.8.12.1667)

Hirose T, O'Brien DA \& Jetten AM 1995 RTR: a new member of the nuclear receptor superfamily that is highly expressed in murine testis. Gene $\mathbf{1 5 2}$ 247-251. (doi:10.1016/0378-1119(94)00656-D)

Hong H, Yang L \& Stallcup MR 1999 Hormone-independent transcriptional activation and coactivator binding by novel orphan nuclear receptor ERR3. Journal of Biological Chemistry 274 22618-22626. (doi:10.1074/ jbc.274.32.22618)

Hong C, Bradley MN, Rong X, Wang X, Wagner A, Grijalva V, Castellani LW, Salazar J, Realegeno S, Boyadjian R et al. $2012 \mathrm{LXR} \alpha$ is uniquely required for maximal reverse cholesterol transport and atheroprotection in ApoE-deficient mice. Journal of Lipid Research 53 1126-1133. (doi:10.1194/jlr.M022061)

Hossain A, Li C \& Saunders GF 2004 Generation of two distinct functional isoforms of dosage-sensitive sex reversal-adrenal hypoplasia congenitacritical region on the $\mathrm{X}$ chromosome gene 1 (DAX-1) by alternative splicing. Molecular Endocrinology 18 1428-1437. (doi:10.1210/ me.2003-0176)

Hu Y-C, Shyr C-R, Che W, Mu X-M, Kim E \& Chang C 2002 Suppression of estrogen receptor-mediated transcription and cell growth by interaction with TR2 orphan receptor. Journal of Biological Chemistry 277 33571-33579. (doi:10.1074/jbc.M203531200)

Huang P, Chandra V \& Rastinejad F 2010 Structural overview of the nuclear receptor superfamily: insights into physiology and therapeutics. Annual Review of Physiology 72 247-272. (doi:10.1146/annurev-physiol021909-135917)

Huang JK, Jarjour AA, Nait Oumesmar B, Kerninon C, Williams A, Krezel W, Kagechika H, Bauer J, Zhao C, Baron-Van Evercooren A et al. 2011 Retinoid X receptor $\gamma$ signaling accelerates CNS remyelination. Nature Neuroscience 14 45-53. (doi:10.1038/nn.2702)

Huh JR, Leung MWL, Huang P, Ryan DA, Krout MR, Malapaka RRV, Chow J, Manel N, Ciofani M, Kim SV et al. 2011 Digoxin and its derivatives 
suppress TH17 cell differentiation by antagonizing ROR $\gamma$ t activity. Nature 472 486-490. (doi:10.1038/nature09978)

Hummelke GC \& Cooney AJ 2001 Germ cell nuclear factor is a transcriptional repressor essential for embryonic development. Frontiers in Bioscience: A Journal and Virtual Library 6 D1186-D1191. (doi:10.2741/Hummelke)

Hwang EJ, Lee JM, Jeong J, Park JH, Yang Y, Lim J-S, Kim JH, Baek SH \& Kim KI 2009 SUMOylation of ROR $\alpha$ potentiates transcriptional activation function. Biochemical and Biophysical Research Communications 378 513-517. (doi:10.1016/j.bbrc.2008.11.072)

Ichiyama K, Yoshida H, Wakabayashi Y, Chinen T, Saeki K, Nakaya M, Takaesu G, Hori S, Yoshimura A \& Kobayashi T 2008 Foxp3 inhibits ROR $\gamma$ t-mediated IL-17A mRNA transcription through direct interaction with ROR $\gamma \mathrm{t}$. Journal of Biological Chemistry $\mathbf{2 8 3}$ 17003-17008. (doi:10.1074/jbc.M801286200)

Ihunnah CA, Jiang M \& Xie W 2011 Nuclear receptor PXR, transcriptional circuits and metabolic relevance. Biochimica et Biophysica Acta 1812 956-963. (doi:10.1016/j.bbadis.2011.01.014)

IJpenberg A, Jeannin E, Wahli W \& Desvergne B 1997 Polarity and specific sequence requirements of peroxisome proliferator-activated receptor (PPAR)/retinoid X receptor heterodimer binding to DNA. A functional analysis of the malic enzyme gene PPAR response element. Journal of Biological Chemistry 272 20108-20117. (doi:10.1074/jbc.272.32.20108)

Ingraham HA \& Redinbo MR 2005 Orphan nuclear receptors adopted by crystallography. Current Opinion in Structural Biology 15 708-715. (doi:10.1016/j.sbi.2005.10.009)

Issemann I \& Green S 1990 Activation of a member of the steroid hormone receptor superfamily by peroxisome proliferators. Nature 347 645-650. (doi:10.1038/347645a0)

Ivanov II, McKenzie BS, Zhou L, Tadokoro CE, Lepelley A, Lafaille JJ, Cua DJ \& Littman DR 2006 The orphan nuclear receptor ROR $\gamma$ t directs the differentiation program of proinflammatory IL-17+T helper cells. Cell 126 1121-1133. (doi:10.1016/j.cell.2006.07.035)

Ivanova N, Dobrin R, Lu R, Kotenko I, Levorse J, DeCoste C, Schafer X, Lun Y \& Lemischka IR 2006 Dissecting self-renewal in stem cells with RNA interference. Nature 442 533-538. (doi:10.1038/nature04915)

Iyer AK \& McCabe ERB 2004 Molecular mechanisms of DAX1 action. Molecular Genetics and Metabolism 83 60-73. (doi:10.1016/j.ymgme. 2004.07.018)

Jetten AM 2009 Retinoid-related orphan receptors (RORs): critical roles in development, immunity, circadian rhythm, and cellular metabolism. Nuclear Receptor Signaling 7 e003. (doi:10.1621/nrs.07003)

Jin L, Martynowski D, Zheng S, Wada T, Xie W \& Li Y 2010 Structural basis for hydroxycholesterols as natural ligands of orphan nuclear receptor ROR $\gamma$. Molecular Endocrinology 24 923-929. (doi:10.1210/me.2009-0507)

Johnston SD, Liu X, Zuo F, Eisenbraun TL, Wiley SR, Kraus RJ \& Mertz JE 1997 Estrogen-related receptor $\alpha 1$ functionally binds as a monomer to extended half-site sequences including ones contained within estrogen-response elements. Molecular Endocrinology 11 342-352. (doi:10.1210/me.11.3.342)

Jonk LJ, de Jonge ME, Pals CE, Wissink S, Vervaart JM, Schoorlemmer J \& Kruijer W 1994 Cloning and expression during development of three murine members of the COUP family of nuclear orphan receptors. Mechanisms of Development 47 81-97. (doi:10.1016/09254773(94)90098-1)

Joseph SB, McKilligin E, Pei L, Watson MA, Collins AR, Laffitte BA, Chen M, Noh G, Goodman J, Hagger GN et al. 2002 Synthetic LXR ligand inhibits the development of atherosclerosis in mice. PNAS 99 7604-7609. (doi:10.1073/pnas.112059299)

Kallen JA, Schlaeppi J-M, Bitsch F, Geisse S, Geiser M, Delhon I \& Fournier B $2002 \mathrm{X}$-ray structure of the hROR $\alpha \mathrm{LBD}$ at $1.63 \mathrm{~A}$ : structural and functional data that cholesterol or a cholesterol derivative is the natural ligand of ROR $\alpha$. Structure 10 1697-1707. (doi:10.1016/S09692126(02)00912-7)

Kallen J, Lattmann R, Beerli R, Blechschmidt A, Blommers MJJ, Geiser M, Ottl J, Schlaeppi J-M, Strauss A \& Fournier B 2007 Crystal structure of human estrogen-related receptor $\alpha$ in complex with a synthetic inverse agonist reveals its novel molecular mechanism. Journal of Biological Chemistry 282 23231-23239. (doi:10.1074/jbc.M703337200)

Kang HS, Okamoto K, Kim Y-S, Takeda Y, Bortner CD, Dang H, Wada T, Xie W, Yang X-P, Liao G et al. 2011 Nuclear orphan receptor TAK1/TR4-deficient mice are protected against obesity-linked inflammation, hepatic steatosis, and insulin resistance. Diabetes 60 177-188. (doi:10.2337/db10-0628)

Kastner P, Grondona JM, Mark M, Gansmuller A, LeMeur M, Decimo D, Vonesch JL, Dollé P \& Chambon P 1994 Genetic analysis of RXR $\alpha$ developmental function: convergence of RXR and RAR signaling pathways in heart and eye morphogenesis. Cell 78 987-1003. (doi:10.1016/0092-8674(94)90274-7)

Kastner P, Mark M, Leid M, Gansmuller A, Chin W, Grondona JM, Décimo D, Krezel W, Dierich A \& Chambon P 1996 Abnormal spermatogenesis in RXR $\beta$ mutant mice. Genes and Development 10 80-92. (doi:10.1101/gad.10.1.80)

Kawamoto T, Sueyoshi T, Zelko I, Moore R, Washburn K \& Negishi M 1999 Phenobarbital-responsive nuclear translocation of the receptor CAR in induction of the CYP2B gene. Molecular and Cellular Biology 19 6318-6322.

Kelly VR, Xu B, Kuick R, Koenig RJ \& Hammer GD 2010 Dax1 up-regulates Oct4 expression in mouse embryonic stem cells via LRH-1 and SRA. Molecular Endocrinology 24 2281-2291. (doi:10.1210/me.2010-0133)

Kersten S, Seydoux J, Peters JM, Gonzalez FJ, Desvergne B \& Wahli W 1999 Peroxisome proliferator-activated receptor $\alpha$ mediates the adaptive response to fasting. Journal of Clinical Investigation 103 1489-1498. (doi:10.1172/JCI6223)

Khan SA, Park SW, Huq M \& Wei L-N 2005 Protein kinase C-mediated phosphorylation of orphan nuclear receptor TR2: effects on receptor stability and activity. Proteomics 5 3885-3894. (doi:10.1002/pmic. 200402062)

Kim YS, Han CY, Kim SW, Kim JH, Lee SK, Jung DJ, Park SY, Kang H, Choi HS, Lee JW et al. 2001 The orphan nuclear receptor small heterodimer partner as a novel coregulator of nuclear factor-kappa $b$ in oxidized low density lipoprotein-treated macrophage cell line RAW 264.7. Journal of Biological Chemistry 276 33736-33740. (doi:10.1074/jbc.M101977200)

Kim E, Xie S, Yeh S-D, Lee Y-F, Collins LL, Hu Y-C, Shyr C-R, Mu X-M, Liu N-C, Chen Y-T et al. 2003 Disruption of TR4 orphan nuclear receptor reduces the expression of liver apolipoprotein E/C-I/C-II gene cluster. Journal of Biological Chemistry 278 46919-46926. (doi:10.1074/jbc.M304088200)

Kim J-Y, Chu K, Kim H-J, Seong H-A, Park K-C, Sanyal S, Takeda J, Ha H, Shong M, Tsai M-J et al. 2004 Orphan nuclear receptor small heterodimer partner, a novel corepressor for a basic helix-loop-helix transcription factor BETA2/neuroD. Molecular Endocrinology 18 776-790. (doi:10.1210/me.2003-0311)

Kim J, Chu J, Shen X, Wang J \& Orkin SH 2008 An extended transcriptional network for pluripotency of embryonic stem cells. Cell 132 1049-1061. (doi:10.1016/j.cell.2008.02.039)

Kim H, Lee JM, Lee G, Bhin J, Oh SK, Kim K, Pyo KE, Lee JS, Yim HY, Kim KI et al. 2011 DNA damage-induced ROR $\alpha$ is crucial for p53 stabilization and increased apoptosis. Molecular Cell 44 797-810. (doi:10.1016/j. molcel.2011.09.023)

Kim YD, Li T, Ahn S-W, Kim D-K, Lee J-M, Hwang S-L, Kim Y-H, Lee C-H, Lee I-K, Chiang JYL et al. 2012 Orphan nuclear receptor small heterodimer partner negatively regulates growth hormone-mediated induction of hepatic gluconeogenesis through inhibition of signal transducer and activator of transcription 5 (STAT5) transactivation. Journal of Biological Chemistry 287 37098-37108. (doi:10.1074/jbc. M112.339887)

Kinsey M, Smith R, Iyer AK, McCabe ERB \& Lessnick SL 2009 EWS/FLI and its downstream target NROB1 interact directly to modulate transcription and oncogenesis in Ewing's sarcoma. Cancer Research 69 9047-9055. (doi:10.1158/0008-5472.CAN-09-1540) 
Kliewer SA, Umesono K, Mangelsdorf DJ \& Evans RM 1992a Retinoid X receptor interacts with nuclear receptors in retinoic acid, thyroid hormone and vitamin D3 signalling. Nature 355 446-449. (doi:10.1038/355446a0)

Kliewer SA, Umesono K, Noonan DJ, Heyman RA \& Evans RM $1992 b$ Convergence of 9-cis retinoic acid and peroxisome proliferator signalling pathways through heterodimer formation of their receptors. Nature 358 771-774. (doi:10.1038/358771a0)

Kliewer SA, Moore JT, Wade L, Staudinger JL, Watson MA, Jones SA, McKee DD, Oliver BB, Willson TM, Zetterström RH et al. 1998 An orphan nuclear receptor activated by pregnanes defines a novel steroid signaling pathway. Cell 92 73-82. (doi:10.1016/S00928674(00)80900-9)

Kliewer SA, Goodwin B \& Willson TM 2002 The nuclear pregnane X receptor: a key regulator of xenobiotic metabolism. Endocrine Reviews 23 687-702. (doi:10.1210/er.2001-0038)

Kobayashi M, Takezawa S, Hara K, Yu RT, Umesono Y, Agata K, Taniwaki M, Yasuda K \& Umesono K 1999 Identification of a photoreceptor cell-specific nuclear receptor. PNAS 96 4814-4819. (doi:10.1073/pnas.96.9.4814)

Kolluri SK, Zhu X, Zhou X, Lin B, Chen Y, Sun K, Tian X, Town J, Cao X, Lin F et al. 2008 A short Nur77-derived peptide converts Bcl-2 from a protector to a killer. Cancer Cell 14 285-298. (doi:10.1016/j.ccr.2008. 09.002)

Krill KT, Gurdziel K, Heaton JH, Simon DP \& Hammer GD 2013 Dicer deficiency reveals microRNAs predicted to control gene expression in the developing adrenal cortex. Molecular Endocrinology 27 754-768. (doi:10.1210/me.2012-1331)

Kritis AA, Argyrokastritis A, Moschonas NK, Power S, Katrakili N, Zannis VI, Cereghini S \& Talianidis I 1996 Isolation and characterization of a third isoform of human hepatocyte nuclear factor 4. Gene 173 275-280. (doi:10.1016/0378-1119(96)00183-7)

Krylova IN, Sablin EP, Moore J, Xu RX, Waitt GM, MacKay JA, Juzumiene D, Bynum JM, Madauss K, Montana V et al. 2005 Structural analyses reveal phosphatidyl inositols as ligands for the NR5 orphan receptors SF-1 and LRH-1. Cell 120 343-355. (doi:10.1016/j.cell.2005.01.024)

Krzyzosiak A, Szyszka-Niagolov M, Wietrzych M, Gobaille S, Muramatsu S \& Krezel W 2010 Retinoid X receptor $\gamma$ control of affective behaviors involves dopaminergic signaling in mice. Neuron 66 908-920. (doi:10.1016/j.neuron.2010.05.004)

Kurebayashi S, Ueda E, Sakaue M, Patel DD, Medvedev A, Zhang F \& Jetten AM 2000 Retinoid-related orphan receptor $\gamma(\operatorname{ROR} \gamma)$ is essential for lymphoid organogenesis and controls apoptosis during thymopoiesis. PNAS 97 10132-10137. (doi:10.1073/pnas.97.18.10132)

Labelle Y, Zucman J, Stenman G, Kindblom LG, Knight J, Turc-Carel C, Dockhorn-Dworniczak B, Mandahl N, Desmaze C \& Peter M 1995 Oncogenic conversion of a novel orphan nuclear receptor by chromosome translocation. Human Molecular Genetics 4 2219-2226. (doi:10.1093/hmg/4.12.2219)

Ladias JA \& Karathanasis SK 1991 Regulation of the apolipoprotein AI gene by ARP-1, a novel member of the steroid receptor superfamily. Science 251 561-565. (doi:10.1126/science.1899293)

Laffitte BA, Kast HR, Nguyen CM, Zavacki AM, Moore DD \& Edwards PA 2000 Identification of the DNA binding specificity and potential target genes for the farnesoid X-activated receptor. Journal of Biological Chemistry 275 10638-10647. (doi:10.1074/jbc.275.14.10638)

Lala DS, Rice DA \& Parker KL 1992 Steroidogenic factor I, a key regulator of steroidogenic enzyme expression, is the mouse homolog of fushi tarazu-factor I. Molecular Endocrinology 6 1249-1258. (doi:10.1210/me. 6.8.1249)

Lalli E \& Sassone-Corsi P 2003 DAX-1, an unusual orphan receptor at the crossroads of steroidogenic function and sexual differentiation. Molecular Endocrinology 17 1445-1453. (doi:10.1210/me.2003-0159)

Lalli E, Doghman M, Latre de Late P, Wakil AE \& Mus-Veteau I 2013 Beyond steroidogenesis: novel target genes for SF-1 discovered by genomics. Molecular and Cellular Endocrinology 371 154-159. (doi:10.1016/j.mce. 2012.11.005)
Lam MTY, Cho H, Lesch HP, Gosselin D, Heinz S, Tanaka-Oishi Y, Benner C, Kaikkonen MU, Kim AS, Kosaka M et al. 2013 Rev-Erbs repress macrophage gene expression by inhibiting enhancer-directed transcription. Nature 498 511-515. (doi:10.1038/nature12209)

Laudet V 1997 Evolution of the nuclear receptor superfamily: early diversification from an ancestral orphan receptor. Journal of Molecular Endocrinology 19 207-226. (doi:10.1677/jme.0.0190207)

Law SW, Conneely OM, DeMayo FJ \& O'Malley BW 1992 Identification of a new brain-specific transcription factor, NURR1. Molecular Endocrinology 6 2129-2135. (doi:10.1210/me.6.12.2129)

Law SW, Conneely OM \& O'Malley BW 1994 Molecular cloning of a novel member of the nuclear receptor superfamily related to the orphan receptor, TR2. Gene Expression 4 77-84.

Lazar MA, Hodin RA, Darling DS \& Chin WW 1989 A novel member of the thyroid/steroid hormone receptor family is encoded by the opposite strand of the rat c-erbA $\alpha$ transcriptional unit. Molecular and Cellular Biology 9 1128-1136.

Lee CH, Chinpaisal C \& Wei LN 1998 A novel nuclear receptor heterodimerization pathway mediated by orphan receptors TR2 and TR4. Journal of Biological Chemistry 273 25209-25215. (doi:10.1074/ jbc.273.39.25209)

Lee Y-F, Lee H-J \& Chang C 2002 Recent advances in the TR2 and TR4 orphan receptors of the nuclear receptor superfamily. Journal of Steroid Biochemistry and Molecular Biology 81 291-308. (doi:10.1016/S09600760(02)00118-8)

Lee Y-K, Schmidt DR, Cummins CL, Choi M, Peng L, Zhang Y, Goodwin B, Hammer RE, Mangelsdorf DJ \& Kliewer SA 2008 Liver receptor homolog-1 regulates bile acid homeostasis but is not essential for feedback regulation of bile acid synthesis. Molecular Endocrinology 22 1345-1356. (doi:10.1210/me.2007-0565)

Lee JM, Kim IS, Kim H, Lee JS, Kim K, Yim HY, Jeong J, Kim JH, Kim J-Y, Lee $\mathrm{H}$ et al. $2010 \mathrm{ROR} \alpha$ attenuates Wnt/ $\beta$-catenin signaling by $\mathrm{PKC} \alpha$ dependent phosphorylation in colon cancer. Molecular Cell $\mathbf{3 7}$ 183-195. (doi:10.1016/j.molcel.2009.12.022)

Lee JM, Lee YK, Mamrosh JL, Busby SA, Griffin PR, Pathak MC, Ortlund EA \& Moore DD 2011a A nuclear-receptor-dependent phosphatidylcholine pathway with antidiabetic effects. Nature 474 506-510. (doi:10.1038/nature10111)

Lee K, Khan S, Ansar M, Santos-Cortez RLP, Ahmad W \& Leal SM $2011 b$ A novel ESRRB deletion is a rare cause of autosomal recessive nonsyndromic hearing impairment among Pakistani families. Genetics Research International 2011 368915. (doi:10.4061/2011/368915)

Lee JM, Lee JS, Kim H, Kim K, Park H, Kim J-Y, Lee SH, Kim IS, Kim J, Lee M et al. $2012 \mathrm{EZH} 2$ generates a methyl degron that is recognized by the DCAF1/DDB1/CUL4 E3 ubiquitin ligase complex. Molecular Cell $\mathbf{4 8}$ 572-586. (doi:10.1016/j.molcel.2012.09.004)

Lefebvre P, Benomar Y \& Staels B 2010 Retinoid X receptors: common heterodimerization partners with distinct functions. Trends in Endocrinology and Metabolism 21 676-683. (doi:10.1016/j.tem.2010.06.009)

Lefterova MI, Zhang Y, Steger DJ, Schupp M, Schug J, Cristancho A, Feng D, Zhuo D, Stoeckert CJ, Liu XS et al. 2008 PPAR and C/EBP factors orchestrate adipocyte biology via adjacent binding on a genome-wide scale. Genes and Development 22 2941-2952. (doi:10.1101/gad.1709008)

Lefterova MI, Steger DJ, Zhuo D, Qatanani M, Mullican SE, Tuteja G, Manduchi E, Grant GR \& Lazar MA 2010 Cell-specific determinants of peroxisome proliferator-activated receptor $\gamma$ function in adipocytes and macrophages. Molecular and Cellular Biology 30 2078-2089. (doi:10.1128/MCB.01651-09)

Lehmann JM, McKee DD, Watson MA, Willson TM, Moore JT \& Kliewer SA 1998 The human orphan nuclear receptor PXR is activated by compounds that regulate CYP3A4 gene expression and cause drug interactions. Journal of Clinical Investigation 102 1016-1023. (doi:10.1172/JCI3703)

Lehrke M \& Lazar MA 2005 The many faces of PPAR $\gamma$. Cell 123 993-999. (doi:10.1016/j.cell.2005.11.026)

Published by Bioscientifica Ltd 
Lehrke M, Lebherz C, Millington SC, Guan H-P, Millar J, Rader DJ, Wilson JM \& Lazar MA 2005 Diet-dependent cardiovascular lipid metabolism controlled by hepatic LXR $\alpha$. Cell Metabolism 1 297-308. (doi:10.1016/ j.cmet.2005.04.005)

Leid M, Kastner P, Lyons R, Nakshatri H, Saunders M, Zacharewski T, Chen J-Y, Staub A, Garnier J-M, Mader S et al. 1992 Purification, cloning, and RXR identity of the HeLa cell factor with which RAR or TR heterodimerizes to bind target sequences efficiently. Cell $\mathbf{6 8}$ 377-395. (doi:10.1016/0092-8674(92)90478-U)

Leone TC, Weinheimer CJ \& Kelly DP 1999 A critical role for the peroxisome proliferator-activated receptor $\alpha$ (PPAR $\alpha$ ) in the cellular fasting response: the PPAR $\alpha$-null mouse as a model of fatty acid oxidation disorders. PNAS 96 7473-7478. (doi:10.1073/pnas.96. 13.7473)

Levin AA, Sturzenbecker LJ, Kazmer S, Bosakowski T, Huselton C, Allenby G, Speck J, Kratzeisen C, Rosenberger M \& Lovey A 1992 9-cis retinoic acid stereoisomer binds and activates the nuclear receptor RXR $\alpha$. Nature 355 359-361. (doi:10.1038/355359a0)

Levin N, Bischoff ED, Daige CL, Thomas D, Vu CT, Heyman RA, Tangirala RK \& Schulman IG 2005 Macrophage liver X receptor is required for antiatherogenic activity of LXR agonists. Arteriosclerosis, Thrombosis, and Vascular Biology 25 135-142. (doi:10.1161/01.ATV.0000178996. 91277.fb)

Li M, Xie YH, Kong YY, Wu X, Zhu L \& Wang Y 1998 Cloning and characterization of a novel human hepatocyte transcription factor, hB1F, which binds and activates enhancer II of hepatitis B virus. Journal of Biological Chemistry 273 29022-29031. (doi:10.1074/jbc.273. 44.29022)

Li Y, Choi M, Cavey G, Daugherty J, Suino K, Kovach A, Bingham NC, Kliewer SA \& Xu HE 2005 Crystallographic identification and functional characterization of phospholipids as ligands for the orphan nuclear receptor steroidogenic factor-1. Molecular Cell 17 491-502. (doi:10.1016/j.molcel.2005.02.002)

Li Q-X, Ke N, Sundaram R \& Wong-Staal F 2006 NR4A1, 2, 3 - an orphan nuclear hormone receptor family involved in cell apoptosis and carcinogenesis. Histology and Histopathology 21 533-540.

Li P, Liu Y, Yi B, Wang G, You X, Zhao X, Summer R, Qin Y \& Sun J 2013 MicroRNA-638 is highly expressed in human vascular smooth muscle cells and inhibits PDGF-BB-induced cell proliferation and migration through targeting orphan nuclear receptor NOR1. Cardiovascular Research 99 185-193. (doi:10.1093/cvr/cvt082)

Lin TM, Young WJ \& Chang C 1995 Multiple functions of the TR2-11 orphan receptor in modulating activation of two key cis-acting elements involved in the retinoic acid signal transduction system. Journal of Biological Chemistry 270 30121-30128. (doi:10.1074/jbc.270. 50.30121)

Lin F-J, Qin J, Tang K, Tsai SY \& Tsai M-J 2011 Coup d'Etat: an orphan takes control. Endocrine Reviews 32 404-421. (doi:10.1210/er.2010-0021)

Lin S-J, Ho H-C, Lee Y-F, Liu N-C, Liu S, Li G, Shyr C-R \& Chang C 2012 Reduced osteoblast activity in the mice lacking TR4 nuclear receptor leads to osteoporosis. Reproductive Biology and Endocrinology 1043. (doi:10.1186/1477-7827-10-43)

Litchfield LM \& Klinge CM 2012 Multiple roles of COUP-TFII in cancer initiation and progression. Journal of Molecular Endocrinology 49 R135-R148. (doi:10.1530/JME-12-0144)

Liu H-K, Wang Y, Belz T, Bock D, Takacs A, Radlwimmer B, Barbus S, Reifenberger G, Lichter P \& Schütz G 2010 The nuclear receptor tailless induces long-term neural stem cell expansion and brain tumor initiation. Genes and Development 24 683-695. (doi:10.1101/gad. 560310)

Luo Y 2012 The function and mechanisms of Nurr1 action in midbrain dopaminergic neurons, from development and maintenance to survival. International Review of Neurobiology 102 1-22. (doi:10.1016/ B978-0-12-386986-9.00001-6)
Luo X, Ikeda Y \& Parker KL 1994 A cell-specific nuclear receptor is essential for adrenal and gonadal development and sexual differentiation. Cell 77 481-490. (doi:10.1016/0092-8674(94)90211-9)

Mages HW, Rilke O, Bravo R, Senger G \& Kroczek RA 1994 NOT, a human immediate-early response gene closely related to the steroid/thyroid hormone receptor NAK1/TR3. Molecular Endocrinology 8 1583-1591. (doi:10.1210/me.8.11.1583)

Makishima M, Okamoto AY, Repa JJ, Tu H, Learned RM, Luk A, Hull MV, Lustig KD, Mangelsdorf DJ \& Shan B 1999 Identification of a nuclear receptor for bile acids. Science $\mathbf{2 8 4}$ 1362-1365. (doi:10.1126/science. 284.5418.1362)

Malewicz M, Kadkhodaei B, Kee N, Volakakis N, Hellman U, Viktorsson K, Leung CY, Chen B, Lewensohn R, van Gent DC et al. 2011 Essential role for DNA-PK-mediated phosphorylation of NR4A nuclear orphan receptors in DNA double-strand break repair. Genes and Development 25 2031-2040. (doi:10.1101/gad.16872411)

Mangelsdorf DJ, Ong ES, Dyck JA \& Evans RM 1990 Nuclear receptor that identifies a novel retinoic acid response pathway. Nature 345 224-229. (doi:10.1038/345224a0)

Mangelsdorf DJ, Borgmeyer U, Heyman RA, Zhou JY, Ong ES, Oro AE, Kakizuka A \& Evans RM 1992 Characterization of three RXR genes that mediate the action of 9-cis retinoic acid. Genes and Development 6 329-344. (doi:10.1101/gad.6.3.329)

Mangelsdorf DJ, Thummel C, Beato M, Herrlich P, Schütz G, Umesono K, Blumberg B, Kastner P, Mark M, Chambon P et al. 1995 The nuclear receptor superfamily: the second decade. Cell 83 835-839. (doi:10.1016/0092-8674(95)90199-X)

Mark M \& Chambon P 2003 Functions of RARs and RXRs in vivo: genetic dissection of the retinoid signaling pathway. Pure and Applied Chemistry 75 1709-1732. (doi:10.1351/pac200375111709)

Mark M, Ghyselinck NB \& Chambon P 2006 Function of retinoid nuclear receptors: lessons from genetic and pharmacological dissections of the retinoic acid signaling pathway during mouse embryogenesis. Annual Review of Pharmacology and Toxicology 46 451-480. (doi:10.1146/ annurev.pharmtox.46.120604.141156)

Markov GV \& Laudet V 2011 Origin and evolution of the ligand-binding ability of nuclear receptors. Molecular and Cellular Endocrinology 334 21-30. (doi:10.1016/j.mce.2010.10.017)

Marks MS, Hallenbeck PL, Nagata T, Segars JH, Appella E, Nikodem VM \& Ozato K 1992 H-2RIIBP (RXR $\beta$ ) heterodimerization provides a mechanism for combinatorial diversity in the regulation of retinoic acid and thyroid hormone responsive genes. EMBO Journal $\mathbf{1 1}$ 1419-1435.

Martello G, Sugimoto T, Diamanti E, Joshi A, Hannah R, Ohtsuka S, Göttgens B, Niwa H \& Smith A 2012 Esrrb is a pivotal target of the Gsk3/Tcf3 axis regulating embryonic stem cell self-renewal. Cell Stem Cell 11 491-504. (doi:10.1016/j.stem.2012.06.008)

Maruyama K, Tsukada T, Ohkura N, Bandoh S, Hosono T \& Yamaguchi K 1998 The NGFI-B subfamily of the nuclear receptor superfamily (review). International Journal of Oncology 12 1237-1243.

Mataki C, Magnier BC, Houten SM, Annicotte J-S, Argmann C, Thomas C, Overmars H, Kulik W, Metzger D, Auwerx J et al. 2007 Compromised intestinal lipid absorption in mice with a liver-specific deficiency of liver receptor homolog 1. Molecular and Cellular Biology 27 8330-8339. (doi:10.1128/MCB.00852-07)

Maxwell MA \& Muscat GEO 2006 The NR4A subgroup: immediate early response genes with pleiotropic physiological roles. Nuclear Receptor Signaling 4 e002. (doi:10.1621/nrs.04002)

McMorrow JP \& Murphy EP 2011 Inflammation: a role for NR4A orphan nuclear receptors? Biochemical Society Transactions 39 688-693. (doi:10.1042/BST0390688)

Medvedev A, Yan ZH, Hirose T, Giguère V \& Jetten AM 1996 Cloning of a cDNA encoding the murine orphan receptor RZR/ROR $\gamma$ and characterization of its response element. Gene 181 199-206. (doi:10.1016/S0378-1119(96)00504-5) 
Miao J, Xiao Z, Kanamaluru D, Min G, Yau PM, Veenstra TD, Ellis E, Strom S, Suino-Powell K, Xu HE et al. 2009 Bile acid signaling pathways increase stability of small heterodimer partner (SHP) by inhibiting ubiquitinproteasomal degradation. Genes and Development 23 986-996. (doi:10.1101/gad.1773909)

Miao J, Choi S-E, Seok SM, Yang L, Zuercher WJ, Xu Y, Willson TM, Xu HE $\&$ Kemper JK 2011 Ligand-dependent regulation of the activity of the orphan nuclear receptor, small heterodimer partner (SHP), in the repression of bile acid biosynthetic CYP7A1 and CYP8B1 genes. Molecular Endocrinology 25 1159-1169. (doi:10.1210/me.2011-0033)

Michalik L 2006 Involvement of PPAR nuclear receptors in tissue injury and wound repair. Journal of Clinical Investigation 116 598-606. (doi:10.1172/JCI27958)

Mikkelsen TS, Xu Z, Zhang X, Wang L, Gimble JM, Lander ES \& Rosen ED 2010 Comparative epigenomic analysis of murine and human adipogenesis. Cell 143 156-169. (doi:10.1016/j.cell.2010.09.006)

Milbrandt J 1988 Nerve growth factor induces a gene homologous to the glucocorticoid receptor gene. Neuron 1 183-188. (doi:10.1016/ 0896-6273(88)90138-9)

Miyajima N, Kadowaki Y, Fukushige S, Shimizu S, Semba K, Yamanashi Y, Matsubara K, Toyoshima K \& Yamamoto T 1988 Identification of two novel members of erbA superfamily by molecular cloning: the gene products of the two are highly related to each other. Nucleic Acids Research 16 11057-11074. (doi:10.1093/nar/16.23.11057)

Modica S, Gadaleta RM \& Moschetta A 2010 Deciphering the nuclear bile acid receptor FXR paradigm. Nuclear Receptor Signaling $\mathbf{8}$ e005 (doi:10.1621/nrs.08005)

Mohan HM, Aherne CM, Rogers AC, Baird AW, Winter DC \& Murphy EP 2012 Molecular pathways: the role of NR4A orphan nuclear receptors in cancer. Clinical Cancer Research 18 3223-3228. (doi:10.1158/ 1078-0432.CCR-11-2953)

Monaghan AP, Bock D, Gass P, Schwäger A, Wolfer DP, Lipp HP \& Schütz G 1997 Defective limbic system in mice lacking the tailless gene. Nature 390 515-517. (doi:10.1038/37364)

Moore DD, Kato S, Xie W, Mangelsdorf DJ, Schmidt DR, Xiao R \& Kliewer SA 2006 International Union of Pharmacology. LXII. The NR1H and NR1I receptors: constitutive androstane receptor, pregnene $\mathrm{X}$ receptor, farnesoid $\mathrm{X}$ receptor $\alpha$, farnesoid $\mathrm{X}$ receptor $\beta$, liver $\mathrm{X}$ receptor $\alpha$, liver X receptor $\beta$, and vitamin D receptor. Pharmacological Reviews 58 742-759. (doi:10.1124/pr.58.4.6)

Moschetta A, Bookout AL \& Mangelsdorf DJ 2004 Prevention of cholesterol gallstone disease by FXR agonists in a mouse model. Nature Medicine 10 1352-1358. (doi:10.1038/nm1138)

Mu X \& Chang C 2003 TR2 orphan receptor functions as negative modulator for androgen receptor in prostate cancer cells PC-3. Prostate 57 129-133. (doi:10.1002/pros.10282)

Mukherjee S \& Mani S 2010 Orphan nuclear receptors as targets for drug development. Pharmaceutical Research 27 1439-1468. (doi:10.1007/ s11095-010-0117-7)

Mullen EM, Gu P \& Cooney AJ 2007 Nuclear receptors in regulation of mouse ES cell pluripotency and differentiation. PPAR Research 2007 61563. (doi:10.1155/2007/61563)

Muscatelli F, Strom TM, Walker AP, Zanaria E, Récan D, Meindl A, Bardoni B, Guioli S, Zehetner G, Rabl W et al. 1994 Mutations in the DAX-1 gene give rise to both $\mathrm{X}$-linked adrenal hypoplasia congenita and hypogonadotropic hypogonadism. Nature 372 672-676. (doi:10.1038/ 372672a0)

Nagy ZS, Czimmerer Z \& Nagy L 2013 Nuclear receptor mediated mechanisms of macrophage cholesterol metabolism. Molecular and Cellular Endocrinology 368 85-98. (doi:10.1016/j.mce.2012.04.003)

Nakai A, Kartha S, Sakurai A, Toback FG \& DeGroot LJ 1990 A human early response gene homologous to murine nur77 and rat NGFI-B, and related to the nuclear receptor superfamily. Molecular Endocrinology 4 1438-1443. (doi:10.1210/mend-4-10-1438)

Navas MA, Munoz-Elias EJ, Kim J, Shih D \& Stoffel M 1999 Functional characterization of the MODY1 gene mutations HNF4(R127W),
HNF4(V255M), and HNF4(E276Q). Diabetes 48 1459-1465. (doi:10.2337/diabetes.48.7.1459)

Nielsen R, Pedersen TA, Hagenbeek D, Moulos P, Siersbaek R, Megens E, Denissov S, Børgesen M, Francoijs K-J, Mandrup S et al. 2008 Genomewide profiling of PPAR $\gamma:$ RXR and RNA polymerase II occupancy reveals temporal activation of distinct metabolic pathways and changes in RXR dimer composition during adipogenesis. Genes and Development 22 2953-2967. (doi:10.1101/gad.501108)

Nishizawa H, Yamagata K, Shimomura I, Takahashi M, Kuriyama H, Kishida K, Hotta K, Nagaretani H, Maeda N, Matsuda M et al. 2002 Small heterodimer partner, an orphan nuclear receptor, augments peroxisome proliferator-activated receptor $\gamma$ transactivation. Journal of Biological Chemistry 277 1586-1592. (doi:10.1074/jbc.M104301200)

Nitta M, Ku S, Brown C, Okamoto AY \& Shan B 1999 CPF: an orphan nuclear receptor that regulates liver-specific expression of the human cholesterol $7 \alpha$-hydroxylase gene. PNAS 96 6660-6665. (doi:10.1073/ pnas.96.12.6660)

Nolte RT, Wisely GB, Westin S, Cobb JE, Lambert MH, Kurokawa R, Rosenfeld MG, Willson TM, Glass CK \& Milburn MV 1998 Ligand binding and co-activator assembly of the peroxisome proliferatoractivated receptor- $\gamma$. Nature 395 137-143. (doi:10.1038/25931)

Nuclear Receptors Nomenclature Committee 1999 A unified nomenclature system for the nuclear receptor superfamily. Cell 97 161-163. (doi:10. 1016/S0092-8674(00)80726-6)

Odom DT, Zizlsperger N, Gordon DB, Bell GW, Rinaldi NJ, Murray HL, Volkert TL, Schreiber J, Rolfe PA, Gifford DK et al. 2004 Control of pancreas and liver gene expression by HNF transcription factors. Science 303 1378-1381. (doi:10.1126/science.1089769)

O'Geen H, Lin Y-H, Xu X, Echipare L, Komashko VM, He D, Frietze S, Tanabe O, Shi L, Sartor MA et al. 2010 Genome-wide binding of the orphan nuclear receptor TR4 suggests its general role in fundamental biological processes. BMC Genomics 11 689. (doi:10.1186/1471-2164-11-689)

Ohkura N, Hijikuro M, Yamamoto A \& Miki K 1994 Molecular cloning of a novel thyroid/steroid receptor superfamily gene from cultured rat neuronal cells. Biochemical and Biophysical Research Communications 205 1959-1965. (doi:10.1006/bbrc.1994.2900)

Onishi A, Peng G-H, Hsu C, Alexis U, Chen S \& Blackshaw S 2009 Pias3dependent SUMOylation directs rod photoreceptor development. Neuron 61 234-246. (doi:10.1016/j.neuron.2008.12.006)

Onishi A, Peng G-H, Poth EM, Lee DA, Chen J, Alexis U, de Melo J, Chen S \& Blackshaw S 2010 The orphan nuclear hormone receptor ERR $\beta$ controls rod photoreceptor survival. PNAS 107 11579-11584. (doi:10.1073/ pnas.1000102107)

Oosterveer MH, Mataki C, Yamamoto H, Harach T, Moullan N, van Dijk TH, Ayuso E, Bosch F, Postic C, Groen AK et al. 2012 LRH-1-dependent glucose sensing determines intermediary metabolism in liver. Journal of Clinical Investigation 122 2817-2826. (doi:10.1172/JCI62368)

Ortlund EA, Lee Y, Solomon IH, Hager JM, Safi R, Choi Y, Guan Z, Tripathy A, Raetz CRH, McDonnell DP et al. 2005 Modulation of human nuclear receptor LRH-1 activity by phospholipids and SHP. Nature Structural \& Molecular Biology 12 357-363. (doi:10.1038/nsmb910)

Pardee KI, Xu X, Reinking J, Schuetz A, Dong A, Liu S, Zhang R, Tiefenbach J, Lajoie G, Plotnikov AN et al. 2009 The structural basis of gas-responsive transcription by the human nuclear hormone receptor REV-ERB $\beta$. PLoS Biology 7 e43. (doi:10.1371/journal.pbio.1000043)

Parks DJ, Blanchard SG, Bledsoe RK, Chandra G, Consler TG, Kliewer SA, Stimmel JB, Willson TM, Zavacki AM, Moore DD et al. 1999 Bile acids: natural ligands for an orphan nuclear receptor. Science 284 1365-1368. (doi:10.1126/science.284.5418.1365)

Parviz F, Matullo C, Garrison WD, Savatski L, Adamson JW, Ning G, Kaestner KH, Rossi JM, Zaret KS \& Duncan SA 2003 Hepatocyte nuclear factor $4 \alpha$ controls the development of a hepatic epithelium and liver morphogenesis. Nature Genetics 34 292-296. (doi:10.1038/ng1175)

Pearen MA \& Muscat GEO 2010 Minireview: nuclear hormone receptor 4A signaling: implications for metabolic disease. Molecular Endocrinology 24 1891-1903. (doi:10.1210/me.2010-0015) 
Pei L, Waki H, Vaitheesvaran B, Wilpitz DC, Kurland IJ \& Tontonoz P 2006 NR4A orphan nuclear receptors are transcriptional regulators of hepatic glucose metabolism. Nature Medicine 12 1048-1055. (doi:10.1038/nm1471)

Pérez E, Bourguet W, Gronemeyer H \& de Lera AR 2012 Modulation of RXR function through ligand design. Biochimica et Biophysica Acta (BBA) Molecular and Cell Biology of Lipids 1821 57-69. (doi:10.1016/j.bbalip. 2011.04.003)

Petersen GM, Amundadottir L, Fuchs CS, Kraft P, Stolzenberg-Solomon RZ, Jacobs KB, Arslan AA, Bueno-de-Mesquita HB, Gallinger S, Gross M et al. 2010 A genome-wide association study identifies pancreatic cancer susceptibility loci on chromosomes 13q22.1, 1q32.1 and 5p15.33 Nature Genetics 42 224-228. (doi:10.1038/ng.522)

Plengvidhya N, Antonellis A, Wogan LT, Poleev A, Borgschulze M, Warram JH, Ryffel GU, Krolewski AS \& Doria A 1999 Hepatocyte nuclear factor- $4 \gamma$ : cDNA sequence, gene organization, and mutation screening in early-onset autosomal-dominant type 2 diabetes. Diabetes 48 2099-2102. (doi:10.2337/diabetes.48.10.2099)

Pondugula SR, Dong H \& Chen T 2009 Phosphorylation and proteinprotein interactions in PXR-mediated CYP3A repression. Expert Opinion on Drug Metabolism \& Toxicology 5 861-873. (doi:10.1517/ 17425250903012360)

Qin J, Wu S-P, Creighton CJ, Dai F, Xie X, Cheng C-M, Frolov A, Ayala G, Lin X, Feng X-H et al. 2013a COUP-TFII inhibits TGF- $\beta$-induced growth barrier to promote prostate tumorigenesis. Nature 493 236-240. (doi:10.1038/nature11674)

Qin Q, Knapinska A, Dobri N, Madoux F, Chase P, Hodder P \& Petrukhin K $2013 b$ In pursuit of synthetic modulators for the orphan retina-specific nuclear receptor NR2E3. Journal of Ocular Pharmacology and Therapeutics 29 298-309. (doi:10.1089/jop.2012.0135)

Qu Q, Sun G, Li W, Yang S, Ye P, Zhao C, Yu RT, Gage FH, Evans RM \& Shi Y 2010 Orphan nuclear receptor TLX activates Wnt/ $\beta$-catenin signalling to stimulate neural stem cell proliferation and self-renewal. Nature Cell Biology 12 31-40 sup pp 1-9. (doi:10.1038/ncb2001)

Rada-Iglesias A, Bajpai R, Prescott S, Brugmann SA, Swigut T \& Wysocka J 2012 Epigenomic annotation of enhancers predicts transcriptional regulators of human neural crest. Cell Stem Cell 11 633-648. (doi:10. 1016/j.stem.2012.07.006)

Raghuram S, Stayrook KR, Huang P, Rogers PM, Nosie AK, McClure DB, Burris LL, Khorasanizadeh S, Burris TP \& Rastinejad F 2007 Identification of heme as the ligand for the orphan nuclear receptors REV-ERB $\alpha$ and REV-ERB $\beta$. Nature Structural \& Molecular Biology 14 1207-1213. (doi:10.1038/nsmb1344)

Ramakrishnan SN \& Muscat GEO 2006 The orphan Rev-erb nuclear receptors: a link between metabolism, circadian rhythm and inflammation? Nuclear Receptor Signaling 4 e009. (doi:10.1621/nrs.04009)

Reinking J, Lam MMS, Pardee K, Sampson HM, Liu S, Yang P, Williams S, White W, Lajoie G, Edwards A et al. 2005 The Drosophila nuclear receptor e75 contains heme and is gas responsive. Cell 122 195-207. (doi:10.1016/j.cell.2005.07.005)

Renaud JP, Harris JM, Downes M, Burke LJ \& Muscat GE 2000 Structurefunction analysis of the Rev-erbA and RVR ligand-binding domains reveals a large hydrophobic surface that mediates corepressor binding and a ligand cavity occupied by side chains. Molecular Endocrinology 14 700-717. (doi:10.1210/me.14.5.700)

Repa JJ, Liang G, Ou J, Bashmakov Y, Lobaccaro JM, Shimomura I, Shan B, Brown MS, Goldstein JL \& Mangelsdorf DJ 2000 Regulation of mouse sterol regulatory element-binding protein-1c gene (SREBP-1c) by oxysterol receptors, LXR $\alpha$ and LXR $\beta$. Genes and Development 14 2819-2830. (doi:10.1101/gad.844900)

Reschly EJ \& Krasowski MD 2006 Evolution and function of the NR1I nuclear hormone receptor subfamily (VDR, PXR, and CAR) with respect to metabolism of xenobiotics and endogenous compounds. Current Drug Metabolism 7 349-365. (doi:10.2174/138920006776873526)

Retnakaran R, Flock G \& Giguère V 1994 Identification of RVR, a novel orphan nuclear receptor that acts as a negative transcriptional regulator. Molecular Endocrinology 8 1234-1244. (doi:10.1210/me.8.9.1234)
Ritchie HH, Wang LH, Tsai S, O'Malley BW \& Tsai MJ 1990 COUP-TF gene: a structure unique for the steroid/thyroid receptor superfamily. Nucleic Acids Research 18 6857-6862. (doi:10.1093/nar/18.23.6857)

Rowe A, Eager NS \& Brickell PM 1991 A member of the RXR nuclear receptor family is expressed in neural-crest-derived cells of the developing chick peripheral nervous system. Development 111 771-778.

Ruse MD Jr, Privalsky ML \& Sladek FM 2002 Competitive cofactor recruitment by orphan receptor hepatocyte nuclear factor $4 \alpha 1$ : modulation by the F domain. Molecular and Cellular Biology 22 1626-1638. (doi:10.1128/MCB.22.6.1626-1638.2002)

Ryseck RP, Macdonald-Bravo H, Mattéi MG, Ruppert S \& Bravo R 1989 Structure, mapping and expression of a growth factor inducible gene encoding a putative nuclear hormonal binding receptor. EMBO Journal $83327-3335$

Sablin EP, Krylova IN, Fletterick RJ \& Ingraham HA 2003 Structural basis for ligand-independent activation of the orphan nuclear receptor LRH-1. Molecular Cell 11 1575-1585. (doi:10.1016/S1097-2765(03)00236-3)

Sablin EP, Woods A, Krylova IN, Hwang P, Ingraham HA \& Fletterick RJ 2008 The structure of corepressor Dax-1 bound to its target nuclear receptor LRH-1. PNAS 105 18390-18395. (doi:10.1073/pnas.0808936105)

Sadovsky Y, Crawford PA, Woodson KG, Polish JA, Clements MA, Tourtellotte LM, Simburger K \& Milbrandt J 1995 Mice deficient in the orphan receptor steroidogenic factor 1 lack adrenal glands and gonads but express P450 side-chain-cleavage enzyme in the placenta and have normal embryonic serum levels of corticosteroids. PNAS 92 1093910943. (doi:10.1073/pnas.92.24.10939)

Saga Y, Kobayashi M, Ohta H, Murai N, Nakai N, Oshima M \& Taketo MM 1999 Impaired extrapyramidal function caused by the targeted disruption of retinoid X receptor RXR $\gamma 1$ isoform. Genes to Cells $\mathbf{4}$ 219-228. (doi:10.1046/j.1365-2443.1999.00253.x)

Saijo K, Winner B, Carson CT, Collier JG, Boyer L, Rosenfeld MG, Gage FH \& Glass CK 2009 A Nurr1/CoREST pathway in microglia and astrocytes protects dopaminergic neurons from inflammation-induced death. Cell 137 47-59. (doi:10.1016/j.cell.2009.01.038)

Sakurada K, Ohshima-Sakurada M, Palmer TD \& Gage FH 1999 Nurr1, an orphan nuclear receptor, is a transcriptional activator of endogenous tyrosine hydroxylase in neural progenitor cells derived from the adult brain. Development 126 4017-4026.

Sanyal S, Kim J-Y, Kim H-J, Takeda J, Lee Y-K, Moore DD \& Choi H-S 2002 Differential regulation of the orphan nuclear receptor small heterodimer partner (SHP) gene promoter by orphan nuclear receptor ERR isoforms. Journal of Biological Chemistry 277 1739-1748. (doi:10.1074/ jbc.M106140200)

Satoh S, Tang K, Iida A, Inoue M, Kodama T, Tsai SY, Tsai M-J, Furuta Y \& Watanabe S 2009 The spatial patterning of mouse cone opsin expression is regulated by bone morphogenetic protein signaling through downstream effector COUP-TF nuclear receptors. Journal of Neuroscience 29 12401-12411. (doi:10.1523/JNEUROSCI.0951-09.2009)

Scearce LM, Laz TM, Hazel TG, Lau LF \& Taub R 1993 RNR-1, a nuclear receptor in the NGFI-B/Nur77 family that is rapidly induced in regenerating liver. Journal of Biological Chemistry 268 8855-8861.

Schimmer BP \& White PC 2010 Minireview: steroidogenic factor 1: its roles in differentiation, development, and disease. Molecular Endocrinology 24 1322-1337. (doi:10.1210/me.2009-0519)

Schoonjans K, Dubuquoy L, Mebis J, Fayard E, Wendling O, Haby C, Geboes K \& Auwerx J 2005 Liver receptor homolog 1 contributes to intestinal tumor formation through effects on cell cycle and inflammation. PNAS 102 2058-2062. (doi:10.1073/pnas.0409756102)

Schuler M, Ali F, Chambon C, Duteil D, Bornert J-M, Tardivel A, Desvergne B, Wahli W, Chambon P \& Metzger D 2006 PGC1 $\alpha$ expression is controlled in skeletal muscles by PPAR $\beta$, whose ablation results in fiber-type switching, obesity, and type 2 diabetes. Cell Metabolism 4 407-414. (doi:10.1016/j.cmet.2006.10.003)

Schupp M \& Lazar MA 2010 Endogenous ligands for nuclear receptors: digging deeper. Journal of Biological Chemistry 285 40409-40415. (doi:10.1074/jbc.R110.182451)

Published by Bioscientifica Ltd 
Sekiya T, Kashiwagi I, Yoshida R, Fukaya T, Morita R, Kimura A, Ichinose H, Metzger D, Chambon P \& Yoshimura A 2013 Nr4a receptors are essential for thymic regulatory $\mathrm{T}$ cell development and immune homeostasis. Nature Immunology 14 230-237. (doi:10.1038/ni.2520)

Semple RK 2006 PPAR and human metabolic disease. Journal of Clinical Investigation 116 581-589. (doi:10.1172/JCI28003)

Seok S, Kanamaluru D, Xiao Z, Ryerson D, Choi S-E, Suino-Powell K, Xu HE, Veenstra TD \& Kemper JK 2013 Bile acid signal-induced phosphorylation of small heterodimer partner by protein kinase $\mathrm{C}$ is critical for epigenomic regulation of liver metabolic genes. Journal of Biological Chemistry 288 23252-23263. (doi:10.1074/jbc.M113.452037)

Seol W, Choi HS \& Moore DD 1996 An orphan nuclear hormone receptor that lacks a DNA binding domain and heterodimerizes with other receptors. Science 272 1336-1339. (doi:10.1126/science.272.5266.1336)

Shi Y, Chichung Lie D, Taupin P, Nakashima K, Ray J, Yu RT, Gage FH \& Evans RM 2004 Expression and function of orphan nuclear receptor TLX in adult neural stem cells. Nature 427 78-83. (doi:10.1038/ nature02211)

Shibata M, Nakao H, Kiyonari H, Abe T \& Aizawa S 2011 MicroRNA-9 regulates neurogenesis in mouse telencephalon by targeting multiple transcription factors. Journal of Neuroscience 31 3407-3422. (doi:10.1523/JNEUROSCI.5085-10.2011)

Shyr C-R, Collins LL, Mu X-M, Platt KA \& Chang C 2002a Spermatogenesis and testis development are normal in mice lacking testicular orphan nuclear receptor 2. Molecular and Cellular Biology 22 4661-4666. (doi:10.1128/MCB.22.13.4661-4666.2002)

Shyr C-R, Hu Y-C, Kim E \& Chang C 2002b Modulation of estrogen receptor-mediated transactivation by orphan receptor TR4 in MCF-7 cells. Journal of Biological Chemistry 277 14622-14628. (doi:10.1074/ jbc.M110051200)

Shyr C-R, Kang H-Y, Tsai M-Y, Liu N-C, Ku P-Y, Huang K-E \& Chang C 2009 Roles of testicular orphan nuclear receptors 2 and 4 in early embryonic development and embryonic stem cells. Endocrinology 150 2454-2462. (doi:10.1210/en.2008-1165)

Sinal CJ, Tohkin M, Miyata M, Ward JM, Lambert G \& Gonzalez FJ 2000 Targeted disruption of the nuclear receptor FXR/BAR impairs bile acid and lipid homeostasis. Cell 102 731-744. (doi:10.1016/ S0092-8674(00)00062-3)

Sladek FM, Zhong WM, Lai E \& Darnell JE Jr 1990 Liver-enriched transcription factor HNF-4 is a novel member of the steroid hormone receptor superfamily. Genes and Development 4 2353-2365. (doi:10.1101/gad.4.12b.2353)

Solomon IH, Hager JM, Safi R, McDonnell DP, Redinbo MR \& Ortlund EA 2005 Crystal structure of the human LRH-1 DBD-DNA complex reveals Ftz-F1 domain positioning is required for receptor activity. Journal of Molecular Biology 354 1091-1102. (doi:10.1016/j.jmb.2005.10.009)

Solt LA \& Burris TP 2012 Action of RORs and their ligands in (patho)physiology. Trends in Endocrinology and Metabolism 23 619-627. (doi:10.1016/j.tem.2012.05.012)

Solt LA, Kumar N, Nuhant P, Wang Y, Lauer JL, Liu J, Istrate MA, Kamenecka TM, Roush WR, Vidović D et al. 2011 Suppression of TH17 differentiation and autoimmunity by a synthetic ROR ligand. Nature 472 491-494. (doi:10.1038/nature10075)

Solt LA, Wang Y, Banerjee S, Hughes T, Kojetin DJ, Lundasen T, Shin Y, Liu J, Cameron MD, Noel R et al. 2012 Regulation of circadian behaviour and metabolism by synthetic REV-ERB agonists. Nature 485 62-68. (doi:10.1038/nature11030)

Sonoda J, Chong LW, Downes M, Barish GD, Coulter S, Liddle C, Lee C-H \& Evans RM 2005 Pregnane X receptor prevents hepatorenal toxicity from cholesterol metabolites. PNAS 102 2198-2203. (doi:10.1073/pnas. 0409481102)

Squires EJ, Sueyoshi T \& Negishi M 2004 Cytoplasmic localization of pregnane $\mathrm{X}$ receptor and ligand-dependent nuclear translocation in mouse liver. Journal of Biological Chemistry 279 49307-49314. (doi:10.1074/jbc.M407281200)
Staudinger JL, Goodwin B, Jones SA, Hawkins-Brown D, MacKenzie KI, LaTour A, Liu Y, Klaassen CD, Brown KK, Reinhard J et al. 2001 The nuclear receptor PXR is a lithocholic acid sensor that protects against liver toxicity. PNAS 98 3369-3374. (doi:10.1073/pnas.051551698)

Stehlin-Gaon C, Willmann D, Zeyer D, Sanglier S, Van Dorsselaer A, Renaud J-P, Moras D \& Schüle R 2003 All-trans retinoic acid is a ligand for the orphan nuclear receptor ROR $\beta$. Nature Structural Biology $\mathbf{1 0}$ 820-825. (doi:10.1038/nsb979)

Sucov HM, Dyson E, Gumeringer CL, Price J, Chien KR \& Evans RM 1994 $\mathrm{RXR} \alpha$ mutant mice establish a genetic basis for vitamin A signaling in heart morphogenesis. Genes and Development 8 1007-1018. (doi:10.1101/gad.8.9.1007)

Sueyoshi T \& Negishi M 2001 Phenobarbital response elements of cytochrome P450 genes and nuclear receptors. Annual Review of Pharmacology and Toxicology 41 123-143. (doi:10.1146/annurev. pharmtox.41.1.123)

Suh JH, Huang J, Park Y-Y, Seong H-A, Kim D, Shong M, Ha H, Lee I-K, Lee K, Wang L et al. 2006 Orphan nuclear receptor small heterodimer partner inhibits transforming growth factor- $\beta$ signaling by repressing SMAD3 transactivation. Journal of Biological Chemistry 281 39169-39178. (doi:10.1074/jbc.M605947200)

Sun G, Yu RT, Evans RM \& Shi Y 2007 Orphan nuclear receptor TLX recruits histone deacetylases to repress transcription and regulate neural stem cell proliferation. PNAS 104 15282-15287. (doi:10.1073/pnas. 0704089104)

Sun C, Nakatake Y, Akagi T, Ura H, Matsuda T, Nishiyama A, Koide H, Ko MSH, Niwa H \& Yokota T 2009 Dax1 binds to Oct3/4 and inhibits its transcriptional activity in embryonic stem cells. Molecular and Cellular Biology 29 4574-4583. (doi:10.1128/MCB.01863-08)

Takayanagi S, Tokunaga T, Liu X, Okada H, Matsushima A \& Shimohigashi Y 2006 Endocrine disruptor bisphenol A strongly binds to human estrogenrelated receptor $\gamma(\mathrm{ERR} \gamma)$ with high constitutive activity. Toxicology Letters 167 95-105. (doi:10.1016/j.toxlet.2006.08.012)

Tang K, Xie X, Park J-I, Jamrich M, Tsai S \& Tsai M-J 2010 COUP-TFs regulate eye development by controlling factors essential for optic vesicle morphogenesis. Development 137 725-734. (doi:10.1242/dev.040568)

Tangirala RK, Bischoff ED, Joseph SB, Wagner BL, Walczak R, Laffitte BA, Daige CL, Thomas D, Heyman RA, Mangelsdorf DJ et al. 2002 Identification of macrophage liver $\mathrm{X}$ receptors as inhibitors of atherosclerosis. PNAS 99 11896-11901. (doi:10.1073/pnas.182199799)

Taubert S, Ward JD \& Yamamoto KR 2011 Nuclear hormone receptors in nematodes: evolution and function. Molecular and Cellular Endocrinology 334 49-55. (doi:10.1016/j.mce.2010.04.021)

Thomas AM, Hart SN, Kong B, Fang J, Zhong X \& Guo GL 2010 Genomewide tissue-specific farnesoid $\mathrm{X}$ receptor binding in mouse liver and intestine. Hepatology 51 1410-1419. (doi:10.1002/hep.23450)

van Tiel CM \& de Vries CJM 2012 NR4All in the vessel wall. Journal of Steroid Biochemistry and Molecular Biology 130 186-193. (doi:10.1016/j.jsbmb. 2011.01.010)

Tolson AH \& Wang H 2010 Regulation of drug-metabolizing enzymes by xenobiotic receptors: PXR and CAR. Advanced Drug Delivery Reviews 62 1238-1249. (doi:10.1016/j.addr.2010.08.006)

Tontonoz P \& Spiegelman BM 2008 Fat and beyond: the diverse biology of PPAR $\gamma$. Annual Review of Biochemistry 77 289-312. (doi:10.1146/ annurev.biochem.77.061307.091829)

Tontonoz P, Hu E, Graves RA, Budavari AI \& Spiegelman BM 1994 mPPAR $\gamma 2$ : tissue-specific regulator of an adipocyte enhancer. Genes and Development 8 1224-1234. (doi:10.1101/gad.8.10.1224)

Tremblay AM \& Giguère V 2007 The NR3B subgroup: an ovERRview. Nuclear Receptor Signaling 5 e009. (doi:10.1621/nrs.05009)

Tremblay GB, Bergeron D \& Giguere V 2001a 4-Hydroxytamoxifen is an isoform-specific inhibitor of orphan estrogen-receptor-related (ERR) nuclear receptors $\beta$ and $\gamma$. Endocrinology 142 4572-4575. (doi:10.1210/ en.142.10.4572)

Tremblay GB, Kunath T, Bergeron D, Lapointe L, Champigny C, Bader JA, Rossant J \& Giguère V $2001 b$ Diethylstilbestrol regulates trophoblast 
stem cell differentiation as a ligand of orphan nuclear receptor ERR $\beta$. Genes and Development 15 833-838. (doi:10.1101/gad.873401)

Tremblay AM, Wilson BJ, Yang X-J \& Giguère V 2008 Phosphorylationdependent sumoylation regulates estrogen-related receptor- $\alpha$ and $-\gamma$ transcriptional activity through a synergy control motif. Molecular Endocrinology 22 570-584. (doi:10.1210/me.2007-0357)

Tsai SY \& Tsai MJ 1997 Chick ovalbumin upstream promoter-transcription factors (COUP-TFs): coming of age. Endocrine Reviews 18 229-240. (doi:10.1210/er.18.2.229)

Tsukiyama T, Ueda H, Hirose S \& Niwa O 1992 Embryonal long terminal repeatbinding protein is a murine homolog of FTZ-F1, a member of the steroid receptor superfamily. Molecular and Cellular Biology 12 1286-1291.

Tugwood JD, Issemann I, Anderson RG, Bundell KR, McPheat WL \& Green S 1992 The mouse peroxisome proliferator activated receptor recognizes a response element in the $5^{\prime}$ flanking sequence of the rat acyl CoA oxidase gene. EMBO Journal 11 433-439.

Uppenberg J, Svensson C, Jaki M, Bertilsson G, Jendeberg L \& Berkenstam A 1998 Crystal structure of the ligand binding domain of the human nuclear receptor PPAR $\gamma$. Journal of Biological Chemistry 273 31108-31112. (doi:10.1074/jbc.273.47.31108)

Uranishi K, Akagi T, Sun C, Koide H \& Yokota T 2013 Dax1 associates with Esrrb and regulates its function in embryonic stem cells. Molecular and Cellular Biology 33 2056-2066. (doi:10.1128/МСB.01520-12)

Valnegri P, Khelfaoui M, Dorseuil O, Bassani S, Lagneaux C, Gianfelice A, Benfante R, Chelly J, Billuart P, Sala C et al. 2011 A circadian clock in hippocampus is regulated by interaction between oligophrenin-1 and Rev-erb $\alpha$. Nature Neuroscience 14 1293-1301. (doi:10.1038/nn.2911)

Vanacker JM, Bonnelye E, Delmarre C \& Laudet V 1998 Activation of the thyroid hormone receptor $\alpha$ gene promoter by the orphan nuclear receptor ERR $\alpha$. Oncogene 17 2429-2435. (doi:10.1038/sj.onc.1202167)

Varga T, Czimmerer Z \& Nagy L 2011 PPARs are a unique set of fatty acid regulated transcription factors controlling both lipid metabolism and inflammation. Biochimica et Biophysica Acta 1812 1007-1022. (doi:10.1016/j.bbadis.2011.02.014)

Wan Y-JY, An D, Cai Y, Repa JJ, Chen TH-P, Flores M, Postic C, Magnuson MA, Chen J, Chien KR et al. 2000 Hepatocyte-specific mutation establishes retinoid $\mathrm{X}$ receptor $\alpha$ as a heterodimeric integrator of multiple physiological processes in the liver. Molecular and Cellular Biology 20 4436-4444. (doi:10.1128/MCB.20.12.4436-4444.2000)

Wang J \& Lazar MA 2008 Bifunctional role of Rev-erb $\alpha$ in adipocyte differentiation. Molecular and Cellular Biology 28 2213-2220. (doi:10.1128/MCB.01608-07)

Wang LH, Tsai SY, Cook RG, Beattie WG, Tsai MJ \& O'Malley BW 1989 COUP transcription factor is a member of the steroid receptor superfamily. Nature 340 163-166. (doi:10.1038/340163a0)

Wang H, Chen J, Hollister K, Sowers LC \& Forman BM 1999 Endogenous bile acids are ligands for the nuclear receptor FXR/BAR. Molecular Cell 3 543-553. (doi:10.1016/S1097-2765(00)80348-2)

Wang Z, Benoit G, Liu J, Prasad S, Aarnisalo P, Liu X, Xu H, Walker NPC \& Perlmann T 2003 Structure and function of Nurr1 identifies a class of ligand-independent nuclear receptors. Nature 423 555-560. (doi:10.1038/nature01645)

Wang J, Rao S, Chu J, Shen X, Levasseur DN, Theunissen TW \& Orkin SH 2006 A protein interaction network for pluripotency of embryonic stem cells. Nature 444 364-368. (doi:10.1038/nature05284)

Wang Y, Kumar N, Solt LA, Richardson TI, Helvering LM, Crumbley C, Garcia-Ordonez RD, Stayrook KR, Zhang X, Novick S et al. 2010 Modulation of retinoic acid receptor-related orphan receptor $\alpha$ and $\gamma$ activity by 7-oxygenated sterol ligands. Journal of Biological Chemistry 285 5013-5025. (doi:10.1074/jbc.M109.080614)

Wang Y, Solt LA, Kojetin DJ \& Burris TP 2012 Regulation of p53 stability and apoptosis by a ROR agonist. PLoS ONE 7 e34921. (doi:10.1371/ journal.pone.0034921)

Wang H, Wang X, Xu X, Zwaka TP \& Cooney AJ 2013 Epigenetic re-programming of the germ cell nuclear factor gene is required for proper differentiation of induced pluripotent cells. Stem Cells [in press]. (doi:10.1002/stem.1367)

Wansa KDSA, Harris JM \& Muscat GEO 2002 The activation function-1 domain of Nur77/NR4A1 mediates trans-activation, cell specificity, and coactivator recruitment. Journal of Biological Chemistry 27733001 33011. (doi:10.1074/jbc.M203572200)

Wansa KDSA, Harris JM, Yan G, Ordentlich P \& Muscat GEO 2003 The AF-1 domain of the orphan nuclear receptor NOR-1 mediates transactivation, coactivator recruitment, and activation by the purine anti-metabolite 6-mercaptopurine. Journal of Biological Chemistry 278 24776-24790. (doi:10.1074/jbc.M300088200)

Warnecke M, Oster H, Revelli J-P, Alvarez-Bolado G \& Eichele G 2005 Abnormal development of the locus coeruleus in Ear2(Nr2f6)-deficient mice impairs the functionality of the forebrain clock and affects nociception. Genes and Development 19 614-625. (doi:10.1101/gad.317905)

Wei P, Zhang J, Egan-Hafley M, Liang S \& Moore DD 2000 The nuclear receptor CAR mediates specific xenobiotic induction of drug metabolism. Nature 407 920-923. (doi:10.1038/35038112)

Wen Z, Pyeon D, Wang Y, Lambert P, Xu W \& Ahlquist P 2012 Orphan nuclear receptor PNR/NR2E3 stimulates p53 functions by enhancing p53 acetylation. Molecular and Cellular Biology 32 26-35. (doi:10.1128/ MCB.05513-11)

Willson TM \& Moore JT 2002 Minireview: genomics versus orphan nuclear receptors - a half-time report. Molecular Endocrinology 16 1135-1144. (doi:10.1210/me.16.6.1135)

Willy PJ, Umesono K, Ong ES, Evans RM, Heyman RA \& Mangelsdorf DJ 1995 LXR, a nuclear receptor that defines a distinct retinoid response pathway. Genes and Development 9 1033-1045. (doi:10.1101/gad.9.9.1033)

Wilson TE, Mouw AR, Weaver CA, Milbrandt J \& Parker KL 1993 The orphan nuclear receptor NGFI-B regulates expression of the gene encoding steroid 21-hydroxylase. Molecular and Cellular Biology 13 861-868.

Wilson BJ, Tremblay AM, Deblois G, Sylvain-Drolet G \& Giguère V 2010 An acetylation switch modulates the transcriptional activity of estrogenrelated receptor $\alpha$. Molecular Endocrinology 24 1349-1358. (doi:10.1210/ me.2009-0441)

Wisely GB, Miller AB, Davis RG, Thornquest AD Jr, Johnson R, Spitzer T, Sefler A, Shearer B, Moore JT, Miller AB et al. 2002 Hepatocyte nuclear factor 4 is a transcription factor that constitutively binds fatty acids. Structure 10 1225-1234. (doi:10.1016/S0969-2126(02)00829-8)

Woldt E, Sebti Y, Solt LA, Duhem C, Lancel S, Eeckhoute J, Hesselink MKC, Paquet C, Delhaye S, Shin Y et al. 2013 Rev-erb- $\alpha$ modulates skeletal muscle oxidative capacity by regulating mitochondrial biogenesis and autophagy. Nature Medicine 19 1039-1046. (doi:10.1038/nm.3213)

Wolf G 2006 Is 9-cis-retinoic acid the endogenous ligand for the retinoic acid-X receptor? Nutrition Reviews 64 532-538.

Wolkenberg SE, Zhao Z, Kapitskaya M, Webber AL, Petrukhin K, Tang YS, Dean DC, Hartman GD \& Lindsley CW 2006 Identification of potent agonists of photoreceptor-specific nuclear receptor (NR2E3) and preparation of a radioligand. Bioorganic \& Medicinal Chemistry Letters 16 5001-5004. (doi:10.1016/j.bmcl.2006.07.056)

Xia X, Jung D, Webb P, Zhang A, Zhang B, Li L, Ayers SD, Gabbi C, Ueno Y, Gustafsson J-Å et al. 2012 Liver $X$ receptor $\beta$ and peroxisome proliferatoractivated receptor $\delta$ regulate cholesterol transport in murine cholangiocytes. Hepatology 56 2288-2296. (doi:10.1002/hep.25919)

Xiao J, Gong A-Y, Eischeid AN, Chen D, Deng C, Young CYF \& Chen X-M 2012 miR-141 modulates androgen receptor transcriptional activity in human prostate cancer cells through targeting the small heterodimer partner protein. Prostate 72 1514-1522. (doi:10.1002/pros.22501)

Xie W, Radominska-Pandya A, Shi Y, Simon CM, Nelson MC, Ong ES, Waxman DJ \& Evans RM 2001 An essential role for nuclear receptors SXR/PXR in detoxification of cholestatic bile acids. PNAS 98 3375-3380. (doi:10.1073/pnas.051014398)

Xie S, Lee Y-F, Kim E, Chen L-M, Ni J, Fang L-Y, Liu S, Lin S-J, Abe J, Berk B et al. $2009 a$ TR 4 nuclear receptor functions as a fatty acid sensor to modulate CD36 expression and foam cell formation. PNAS 106 13353-13358. (doi:10.1073/pnas.0905724106) 
Xie Y-B, Park J-H, Kim D-K, Hwang JH, Oh S, Park SB, Shong M, Lee I-K \& Choi H-S 2009b Transcriptional corepressor SMILE recruits SIRT1 to inhibit nuclear receptor estrogen receptor-related receptor $\gamma$ transactivation. Journal of Biological Chemistry 284 28762-28774. (doi:10.1074/ jbc.M109.034165)

Xie S, Ni J, Lee Y-F, Liu S, Li G, Shyr C-R \& Chang C 2011 Increased acetylation in the DNA-binding domain of TR4 nuclear receptor by the coregulator ARA55 leads to suppression of TR4 transactivation. Journal of Biological Chemistry 286 21129-21136. (doi:10.1074/jbc.M110.208181)

Xu HE, Lambert MH, Montana VG, Parks DJ, Blanchard SG, Brown PJ, Sternbach DD, Lehmann JM, Wisely GB, Willson TM et al. 1999 Molecular recognition of fatty acids by peroxisome proliferator-activated receptors. Molecular Cell 3 397-403. (doi:10.1016/S1097-2765(00)80467-0)

Xu HE, Lambert MH, Montana VG, Plunket KD, Moore LB, Collins JL, Oplinger JA, Kliewer SA, Gampe RT, McKee DD et al. 2001 Structural determinants of ligand binding selectivity between the peroxisome proliferator-activated receptors. PNAS 98 13919-13924. (doi:10.1073/ pnas.241410198)

Xu B, Yang W-H, Gerin I, Hu C-D, Hammer GD \& Koenig RJ 2009 Dax-1 and steroid receptor RNA activator (SRA) function as transcriptional coactivators for steroidogenic factor 1 in steroidogenesis. Molecular and Cellular Biology 29 1719-1734. (doi:10.1128/MCB.01010-08)

Yamagata K, Furuta H, Oda N, Kaisaki PJ, Menzel S, Cox NJ, Fajans SS, Signorini S, Stoffel M \& Bell GI 1996 Mutations in the hepatocyte nuclear factor- $4 \alpha$ gene in maturity-onset diabetes of the young (MODY1). Nature 384 458-460. (doi:10.1038/384458a0)

Yan ZH, Karam WG, Staudinger JL, Medvedev A, Ghanayem BI \& Jetten AM 1998 Regulation of peroxisome proliferator-activated receptor $\alpha$-induced transactivation by the nuclear orphan receptor TAK1/TR4. Journal of Biological Chemistry 273 10948-10957. (doi:10.1074/jbc.273.18.10948)

Yang XO, Pappu BP, Nurieva R, Akimzhanov A, Kang HS, Chung Y, Ma L, Shah B, Panopoulos AD, Schluns KS et al. 2008 T helper 17 lineage differentiation is programmed by orphan nuclear receptors $\operatorname{ROR} \alpha$ and ROR $\gamma$. Immunity 28 29-39. (doi:10.1016/j.immuni.2007.11.016)

Yang D, Li T, Wang Y, Tang Y, Cui H, Tang Y, Zhang X, Chen D, Shen N \& Le W 2012 miR-132 regulates the differentiation of dopamine neurons by directly targeting Nurr1 expression. Journal of Cell Science $\mathbf{1 2 5}$ 1673-1682. (doi:10.1242/jcs.086421)

Yin L, Wu N, Curtin JC, Qatanani M, Szwergold NR, Reid RA, Waitt GM, Parks DJ, Pearce KH, Wisely GB et al. 2007 Rev-erb $\alpha$, a heme sensor that coordinates metabolic and circadian pathways. Science 318 1786-1789. (doi:10.1126/science.1150179)

Yin L, Wu N \& Lazar MA 2010 Nuclear receptor Rev-erb $\alpha$ : a heme receptor that coordinates circadian rhythm and metabolism. Nuclear Receptor Signaling 8 e001. (doi:10.1621/nrs.08001)

Yokoyama A, Takezawa S, Schule R, Kitagawa H \& Kato S 2008 Transrepressive function of TLX requires the histone demethylase LSD1. Molecular and Cellular Biology 28 3995-4003. (doi:10.1128/MCB.02030-07)

Young KA, Berry ML, Mahaffey CL, Saionz JR, Hawes NL, Chang B, Zheng QY, Smith RS, Bronson RT, Nelson RJ et al. 2002 Fierce: a new mouse deletion of Nr2e1; violent behaviour and ocular abnormalities are background-dependent. Behavioural Brain Research 132 145-158. (doi:10.1016/S0166-4328(01)00413-2)

Yu VC, Delsert C, Andersen B, Holloway JM, Devary OV, Näär AM, Kim SY, Boutin J-M, Glass CK \& Rosenfeld MG 1991 RXRß: a coregulator that enhances binding of retinoic acid, thyroid hormone, and vitamin D receptors to their cognate response elements. Cell 67 1251-1266. (doi:10.1016/0092-8674(91)90301-E)

Yu RT, Chiang MY, Tanabe T, Kobayashi M, Yasuda K, Evans RM \& Umesono K 2000 The orphan nuclear receptor Tlx regulates Pax2 and is essential for vision. PNAS 97 2621-2625. (doi:10.1073/pnas.050566897)
Yuan X, Ta TC, Lin M, Evans JR, Dong Y, Bolotin E, Sherman MA Forman BM \& Sladek FM 2009 Identification of an endogenous ligand bound to a native orphan nuclear receptor. PLOS ONE 4 e5609. (doi:10.1371/journal.pone.0005609)

Yuk J-M, Shin D-M, Lee H-M, Kim J-J, Kim S-W, Jin HS, Yang C-S, Park KA, Chanda D, Kim D-K et al. 2011 The orphan nuclear receptor SHP acts as a negative regulator in inflammatory signaling triggered by Toll-like receptors. Nature Immunology 12 742-751. (doi:10.1038/ni.2064)

Zanaria E, Muscatelli F, Bardoni B, Strom TM, Guioli S, Guo W, Lalli E, Moser C, Walker AP, McCabe ERB et al. 1994 An unusual member of the nuclear hormone receptor superfamily responsible for X-linked adrenal hypoplasia congenita. Nature 372 635-641. (doi:10.1038/372635a0)

Zhan Y, Du X, Chen H, Liu J, Zhao B, Huang D, Li G, Xu Q, Zhang M, Weimer BC et al. 2008 Cytosporone B is an agonist for nuclear orphan receptor Nur77. Nature Chemical Biology 4 548-556. (doi:10.1038/ nchembio.106)

Zhan Q, Fang Y, He Y, Liu H-X, Fang J \& Wan Y-JY 2012 Function annotation of hepatic retinoid $\mathrm{X}$ receptor $\alpha$ based on genome-wide DNA binding and transcriptome profiling. PLOS ONE 7 e50013. (doi:10.1371/journal.pone.0050013)

Zhang C-L, Zou Y, Yu RT, Gage FH \& Evans RM 2006 Nuclear receptor TLX prevents retinal dystrophy and recruits the corepressor atrophin 1. Genes and Development 20 1308-1320. (doi:10.1101/gad.1413606)

Zhang Y, Breevoort SR, Angdisen J, Fu M, Schmidt DR, Holmstrom SR, Kliewer SA, Mangelsdorf DJ \& Schulman IG 2012 Liver LXR $\alpha$ expression is crucial for whole body cholesterol homeostasis and reverse cholesterol transport in mice. Journal of Clinical Investigation 122 1688-1699. (doi:10.1172/JCI59817)

Zhao Y \& Bruemmer D 2010 NR4A orphan nuclear receptors transcriptional regulators of gene expression in metabolism and vascular biology. Arteriosclerosis, Thrombosis, and Vascular Biology 30 1535-1541. (doi:10. 1161/ATVBAHA.109.191163)

Zhao C, Sun G, Li S \& Shi Y 2009 A feedback regulatory loop involving microRNA-9 and nuclear receptor TLX in neural stem cell fate determination. Nature Structural \& Molecular Biology 16 365-371. (doi:10.1038/nsmb.1576)

Zhao C, Sun G, Li S, Lang M-F, Yang S, Li W \& Shi Y 2010 MicroRNA let-7b regulates neural stem cell proliferation and differentiation by targeting nuclear receptor TLX signaling. PNAS 107 1876-1881. (doi:10.1073/ pnas.0908750107)

Zhou L, Lopes JE, Chong MMW, Ivanov II, Min R, Victora GD, Shen Y, Du J, Rubtsov YP, Rudensky AY et al. 2008 TGF- $\beta$-induced Foxp3 inhibits $\mathrm{T}(\mathrm{H}) 17$ cell differentiation by antagonizing ROR $\gamma \mathrm{t}$ function. Nature $\mathbf{4 5 3}$ 236-240. (doi:10.1038/nature06878)

Zhou C, King N, Chen KY \& Breslow JL 2009 Activation of PXR induces hypercholesterolemia in wild-type and accelerates atherosclerosis in apoE deficient mice. Journal of Lipid Research 50 2004-2013. (doi:10.1194/jlr.M800608-JLR200)

Zhou XE, Suino-Powell KM, Xu Y, Chan C-W, Tanabe O, Kruse SW, Reynolds R, Engel JD \& Xu HE 2011 The orphan nuclear receptor TR4 is a vitamin A-activated nuclear receptor. Journal of Biological Chemistry 286 2877-2885. (doi:10.1074/jbc.M110.168740)

Zhu XG, Park KS, Kaneshige M, Bhat MK, Zhu Q, Mariash CN, McPhie P \& Cheng SY 2000 The orphan nuclear receptor Ear-2 is a negative coregulator for thyroid hormone nuclear receptor function. Molecular and Cellular Biology 20 2604-2618. (doi:10.1128/MCB.20.7.2604-2618.2000)

Zou Y, Niu W, Qin S, Downes M, Burns DK \& Zhang C-L 2012 The nuclear receptor TLX is required for gliomagenesis within the adult neurogenic niche. Molecular and Cellular Biology 32 4811-4820. (doi:10.1128/MCB. 01122-12)

Received in final form 3 October 2013

Accepted 4 October 2013

Accepted Preprint published online 4 October 2013 http://jme.endocrinology-journals.org DOI: 10.1530/JME-13-0212
() 2013 Society for Endocrinology Printed in Great Britain
Published by Bioscientifica Ltd 